\title{
Calcium-Mediated Abiotic Stress Signaling in Roots
}

\author{
Katie A. Wilkins, Elsa Matthus, Stéphanie M. Swarbreck and Julia M. Davies* \\ Department of Plant Sciences, University of Cambridge, Cambridge, UK
}

Roots are subjected to a range of abiotic stresses as they forage for water and nutrients. Cytosolic free calcium is a common second messenger in the signaling of abiotic stress. In addition, roots take up calcium both as a nutrient and to stimulate exocytosis in growth. For calcium to fulfill its multiple roles must require strict spatiotemporal regulation of its uptake and efflux across the plasma membrane, its buffering in the cytosol and its sequestration or release from internal stores. This prompts the question of how specificity of signaling output can be achieved against the background of calcium's other uses. Threats to agriculture such as salinity, water availability and hypoxia are signaled through calcium. Nutrient deficiency is also emerging as a stress that is signaled through cytosolic free calcium, with progress in potassium, nitrate and boron deficiency signaling now being made. Heavy metals have the capacity to trigger or modulate root calcium signaling depending on their dose and their capacity to catalyze production of hydroxyl radicals. Mechanical stress and cold stress can both trigger an increase in root cytosolic free calcium, with the possibility of membrane deformation playing a part in initiating the calcium signal. This review addresses progress in identifying the calcium transporting proteins (particularly channels such as annexins and cyclic nucleotide-gated channels) that effect stress-induced calcium increases in roots and explores links to reactive oxygen species, lipid signaling, and the unfolded protein response.

Keywords: abiotic stress, calcium, heavy metal, hypoxia, nutrition, salinity, signaling

\section{INTRODUCTION}

Plant roots are exposed to a variety of abiotic stresses as they navigate the soil, foraging for nutrients and water. Cytosolic free calcium $\left(\left[\mathrm{Ca}^{2+}\right]_{\mathrm{cyt}}\right)$ is central to the response to these stresses, acting as a second messenger but also driving exocytosis (Carroll et al., 1998). Specificity of $\left[\mathrm{Ca}^{2+}\right]_{\mathrm{cyt}}$ signaling is determined by the amplitude and duration (and possible oscillation) of the $\left[\mathrm{Ca}^{2+}\right]_{\text {cyt }}$ increase, often referred to as the "signature"' (McAinsh and Pittman, 2009), that is elicited by the stimulus. This signature would be driven by the opening of plasma membrane (PM) and endomembrane $\mathrm{Ca}^{2+}$-permeable channels and terminated by the activity of $\mathrm{Ca}^{2+}$ efflux transporters in those membranes, plus $\mathrm{Ca}^{2+}$-binding proteins, to restore the resting $\left[\mathrm{Ca}^{2+}\right]_{\mathrm{cyt}}$ of 100-200 nM. Use of organelle-targeted $\mathrm{Ca}^{2+}$ reporting proteins has shown that the $\mathrm{Ca}^{2+}$ content of the endoplasmic reticulum (ER) and Golgi increases after stress-induced transient increases in $\left[\mathrm{Ca}^{2+}\right]_{\text {cyt }}$, strongly suggesting that $\mathrm{Ca}^{2+}$ is sequestered there to terminate the $\left[\mathrm{Ca}^{2+}\right]_{\text {cyt }}$ signal (Ordenes et al., 2012; Bonza et al., 2013). Transport of $\mathrm{Ca}^{2+}$ into organelles is catalyzed by $\mathrm{Ca}^{2+}$-ATPases. There are two distinct families: The $\underline{\text { Auto-inhibited }} \underline{\mathrm{Ca}}^{2+}$ - $\underline{\mathrm{ATP}}$-Pses, ACA (that also 
operate at the PM) and the ER $\mathrm{Ca}^{2+}$-ATPases, ECA; reviewed by Bonza et al., 2016). The lower affinity CAX (Cation $/ \mathrm{H}^{+}$ Exchangers) appear to be restricted to endomembranes but also facilitate $\mathrm{Ca}^{2+}$ sequestration (Connorton et al., 2012). Changes in organelle free $\mathrm{Ca}^{2+}$ in roots could also play a part in signaling, most notably in the formation of symbioses and cell death (Stael et al., 2012; Zhao et al., 2013; Wagner et al., 2015). Decoding the $\left[\mathrm{Ca}^{2+}\right]_{\text {cyt }}$ signature will be effected by specific $\mathrm{Ca}^{2+}$-binding proteins. Calmodulins (CaMs) and Calmodulinlike proteins (CMLs) are encoded by multi-gene families in plants. They lack kinase domains, suggesting these proteins must target others with enzymatic activity. CaMs modulate transcription by binding to Calmodulin-binding Transcription Activators (CAMTAs) (Virdi et al., 2015). Other multi-gene families are also evident for $\mathrm{Ca}^{2+}$-Dependent Protein Kinases (CPKs) and Calcineurin-B Like proteins (CBLs). The latter target CBL-Interacting Protein Kinases (CIPKs) to effect cellular responses (Thoday-Kennedy et al., 2015). Changes in $\left[\mathrm{Ca}^{2+}\right]_{\text {cyt }}$ also have the potential to activate lipid signaling pathways. A somewhat forgotten aspect of $\mathrm{Ca}^{2+}$ signaling is the $\mathrm{Ca}^{2+}$ activation of members of the Phospholipase $\mathrm{C}$ and Phospholipase D families (Qin et al., 1997; Hunt et al., 2004; Dressler et al., 2014; Ruelland et al., 2015; Hou et al., 2016). Phospholipase C catalyses production of diacylglycerol and inositol trisphosphate $\left(\operatorname{InsP}_{3}\right)$ while Phospholipase $\mathrm{D}$ catalyses production of phosphatidic acid, thus $\left[\mathrm{Ca}^{2+}\right]_{\text {cyt }}$ would have the capacity to trigger distinct lipid signals depending on the location and $\mathrm{Ca}^{2+}$-sensitivity of the phospholipases. Targets of lipid signals have been reviewed recently by Hou et al. (2016).

The vast majority of $\left[\mathrm{Ca}^{2+}\right]_{\text {cyt }}$ measurements are from Arabidopsis thaliana seedlings and guard cells, achieved using the luminescent $\mathrm{Ca}^{2+}$-interacting aequorin protein. Far fewer studies have focused specifically on roots or utilized the greater sensitivity and spatial resolution of ratiometric fluorescent dyes. The genetically encoded YC3.6 $\mathrm{Ca}^{2+}$ reporter is now being used for both Arabidopsis and rice roots (Behera et al., 2015), holding much promise for the future. It is now clear that an identical stimulus can elicit markedly different root $\left[\mathrm{Ca}^{2+}\right]_{\text {cyt }}$ signatures depending on genus. So far, rice root $\left[\mathrm{Ca}^{2+}\right]_{c y t}$ signals have been found to be lower in amplitude but of longer duration than those of Arabidopsis (Behera et al., 2015).

Electrophysiological studies of root cell plasma membrane (PM) have advanced our understanding of the $\mathrm{Ca}^{2+}$ influx routes that could generate $\left[\mathrm{Ca}^{2+}\right]_{\text {cyt }}$ signatures. There is a central role for PM voltage in $\left[\mathrm{Ca}^{2+}\right]_{\text {cyt }}$ signaling, as individual stresses can hyperpolarize (render it more negative) or depolarize (render it less negative). Manipulating PM voltage elicits distinct $\left[\mathrm{Ca}^{2+}\right]_{c y t}$ signatures and resultant transcriptional responses (Whalley et al., 2011; Whalley and Knight, 2013). Studies on root epidermal and root hair PM have shown that this membrane harbors channels that are activated by hyperpolarized voltage (HyperpolarizationActivated $\underline{\mathrm{Ca}}^{2+}$ Channels (HACCs); Véry and Davies, 2000; Demidchik et al., 2002, 2009; Ma et al., 2012), DepolarizationActivated $\underline{\mathrm{Ca}}^{2+}$ Channels (DACCS); Demidchik et al., 2002; Miedema et al., 2008) and Voltage-Independent $\underline{\mathrm{Ca}}^{2+} \underline{\text { Channels }}$ (VICCs) (Demidchik et al., 2002). Thus changes in voltage would activate specific suites of channels to generate a signature. An

\section{Elongation Zone}

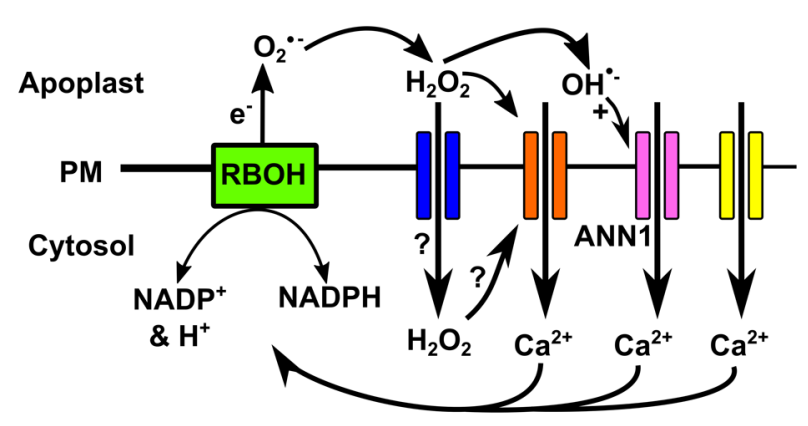

FIGURE 1 | Reactive oxygen species (ROS) regulation of $\mathrm{PM} \mathrm{Ca}^{2+}$ channels in the Arabidopsis root elongation zone epidermis. NADPH oxidases $(\mathrm{RBOH})$ generate extracellular superoxide anion that can undergo conversion to $\mathrm{H}_{2} \mathrm{O}_{2}$ and hydroxyl radicals $\left(\mathrm{OH}^{\prime}\right)$ (Richards et al., 2015). $\mathrm{H}_{2} \mathrm{O}_{2}$ could activate HACC (orange) at the extracellular PM face or enter the cytosol through aquaporins (blue) to activate at the cytosolic face (directly or indirectly) (Demidchik et al., 2007). Extracellular hydroxyl radicals activate Annexin 1 (pink) (Demidchik et al., 2003; Foreman et al., 2003; Laohavisit et al., 2012). $\mathrm{Ca}^{2+}$ influx would depolarise the PM and if unopposed this could activate DACCs (yellow) (Demidchik et al., 2002). Increased $\left[\mathrm{Ca}^{2+}\right]_{\text {cyt }}$ could further activate $\mathrm{RBOH}$.

additional tier of regulation of the $\mathrm{PM} \mathrm{Ca}{ }^{2+}$ influx routes is afforded by reactive oxygen species (ROS) that are produced during development and stress responses (Figure 1). This regulation depends on the specific ROS, its position, the cell type and the cell's developmental state. In Arabidopsis roots, sensitivity of $\mathrm{PM} \mathrm{Ca}^{2+}$ channel activation by extracellular $\mathrm{H}_{2} \mathrm{O}_{2}$ decreases as epidermal cells mature but is still greater than that of the cortex (Demidchik et al., 2007). A similar picture emerges for extracellular hydroxyl radicals, which elicit greater $\mathrm{PM} \mathrm{Ca}{ }^{2+}$ influx currents in the epidermis and root hairs than the pericycle (Demidchik et al., 2003; Foreman et al., 2003). In epidermal PM of the elongation zone, extracellular hydroxyl radicals elicit different $\mathrm{Ca}^{2+}$ channel activity to extracellular $\mathrm{H}_{2} \mathrm{O}_{2}$ (Demidchik et al., 2003, 2007). Thus, ROS will play a significant part of generating cell-specific $\left[\mathrm{Ca}^{2+}\right]_{\text {cyt }}$ signatures in response to stress.

Stress-induced $\left[\mathrm{Ca}^{2+}\right]_{\text {cyt }}$ elevation in roots remains poorly understood in terms of the genes encoding the PM or endo membrane $\mathrm{Ca}^{2+}$ channels involved. Plants have multi-gene families of Glutamate Receptor-Like channels (GLR; activated by a range of extracellular nitrogenous ligands) and $\underline{C y c l i c}$ Nucleotide-Gated channels (CNGC; activated by intracellular cyclic nucleotides), with each gene encoding a potential subunit of a potentially tetrameric channel. Some members have been characterized as having $\mathrm{Ca}^{2+}$ channel forming ability (reviewed by Swarbreck et al., 2013 and Weiland et al., 2016). Membrane residency has yet to be determined for all proteins and while the majority tested are in the PM, in Arabidopsis GLR3.5 has been localized to both mitochondria and chloroplast, depending on its splicing variant (Teardo et al., 2015), CNGC19 to the vacuole (Yuen and Christopher, 2013) and CNGC20 potentially to both PM and vacuole (Fischer et al., 2013; Yuen and Christopher, 
2013). Mechanosensitive $\mathrm{Ca}^{2+}$ channels of the PM have also been identified (Nakagawa et al., 2007; Hou et al., 2014; Yuan et al., 2014; Kamano et al., 2015), as has a vacuolar $\mathrm{Ca}^{2+}$ efflux channel TPC1 (Two Pore Channel1; Peiter et al., 2005). Root cells will express specific complements of these genes and their transcription can change under abiotic stress (Dinneny et al., 2008; Roy et al., 2008), with the implication that stress resets the $\left[\mathrm{Ca}^{2+}\right]_{\text {cyt }}$ signaling system.

The threat of abiotic stress is global. Drought threatens plant productivity across continents, with water shortage not only imposing an osmotic challenge but also leading to soil hardness that roots must overcome. Changing weather patterns are bringing greater rainfalls to some areas (particularly Northern Europe) thus leading to the threat of hypoxic challenge from waterlogged soil (Shabala et al., 2014). Salinity stress arising from sodic soils is made worse by irrigation and counteracting nutritional deprivation by fertilizer application comes with an increasing economic and environmental cost. In this review, the effects of salinity, water availability (including soil hardness), nutritional deprivation, heavy metals and cold on root $\left[\mathrm{Ca}^{2+}\right]_{\mathrm{cyt}}$ will be addressed. The candidate channels for elevating $\left[\mathrm{Ca}^{2+}\right]_{\text {cyt }}$ in roots will be introduced and the downstream consequences of the signal will be reviewed.

\section{SALINITY STRESS FROM CHANNEL TO TRANSCRIPTION}

The transporters for $\mathrm{Na}^{+}$influx into the root are not fully known but include the PM cyclic nucleotide-gated channels CNGC3 (Gobert et al., 2006) and CNGC10 (Guo et al., 2008; Jin et al., 2015) in Arabidopsis. $\mathrm{Na}^{+}$ingress is opposed by the Annexin1 protein and the AGB1 heterotrimeric G protein subunit in Arabidopsis roots (Laohavisit et al., 2013; Yu and Assmann, 2015). The mechanisms for sensing the increase in cytosolic $\mathrm{Na}^{+}$remain obscure (Maathuis, 2014; Shabala et al., 2015) however what is clear is that $\mathrm{Na}^{+}$entry depolarizes the root epidermal PM voltage (Maathuis, 2014). This is significant in that it implicates depolarization-activated and voltage-independent $\mathrm{PM} \mathrm{Ca}{ }^{2+}$-permeable channels in generating the transient $\left[\mathrm{Ca}^{2+}\right]_{\text {cyt }}$ increases observed in roots in response to $\mathrm{NaCl}$ (Figure 2). Both channels types are present in Arabidopsis root epidermal PM (Demidchik et al., 2002). However, involvement of hyperpolarization-activated $\mathrm{PM} \mathrm{Ca}{ }^{2+}$ channels should not be dismissed because increasing $\left[\mathrm{Ca}^{2+}\right]_{\text {cyt }}$ shifts their activation voltage to more depolarized values (Véry and Davies, 2000; Demidchik et al., 2002) and they are implicated in the Arabidopsis root response to $\mathrm{NaCl}$ (Ma et al., 2012; Laohavisit et al., 2013).

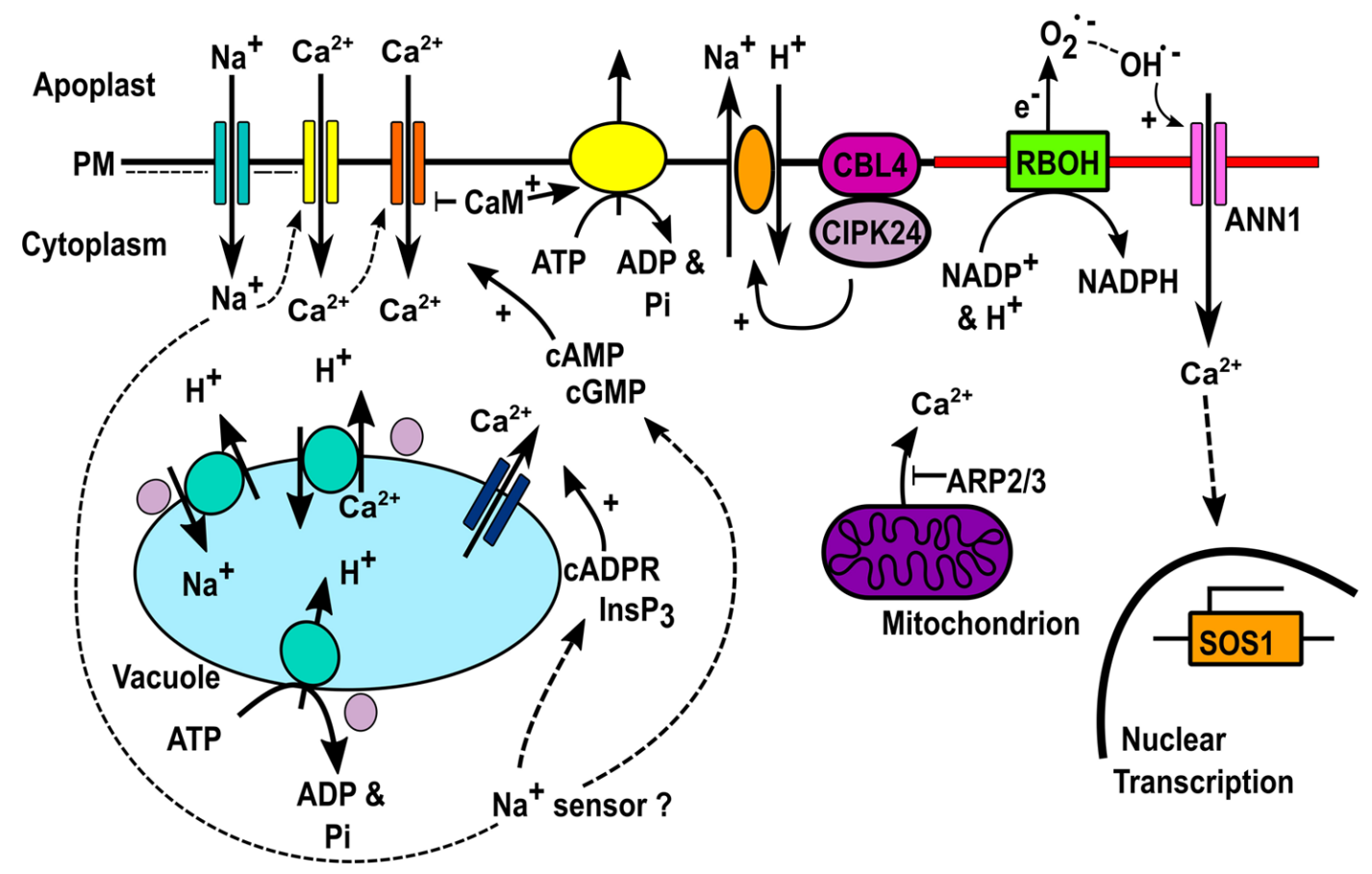

FIGURE 2 | $\mathbf{C a}^{2+}$ transporters in salinity-stress signaling. $\mathrm{Na}^{+}$enters root epidermis and depolarises the PM, possibly activating DACCs (yellow) with the $\left[\mathrm{Ca}^{2+}\right]_{\text {cyt }}$ increase also possibly activating HACCs (orange). $\mathrm{Na}^{+}$sensing results in cGMP/CAMP production that could activate CNGC HACCs (Shabala et al., 2015). $\mathrm{InsP}_{3}$ and cADPR production causes $\mathrm{Ca}^{2+}$ release from stores by unknown channels (DeWald et al., 2001; Tracy et al., 2008; Zhang Y. et al., 2015; Zhang X. et al., 2015). ARP2/3 restricts mitochondrial $\mathrm{Ca}^{2+}$ efflux (Zhao et al., 2013). [ $\left.\mathrm{Ca}^{2+}\right]_{\text {cyt }}$ activation of RBOH NADPH oxidase activity would promote extracellular hydroxyl radical formation and activation of Annexin1-mediated $\mathrm{Ca}^{2+}$ influx (pink) (Laohavisit et al., 2013). We hypothesize that these are held in a microdomain (red). This leads to SOS1 transcription (Laohavisit et al., 2013). CaM activation would restrict CNGC-mediated $\mathrm{Ca}^{2+}$ influx and promote efflux by ACA Ca ${ }^{2+}$-ATPase activation (Boursiac and Harper, 2007). [ $\left.\mathrm{Ca}^{2+}\right]_{\text {cyt }}$ elevation activates CBL4 and CIPK24 (purple) leading to SOS1-mediated Na+ extrusion (Liu et al., 2000$)$. CIPK24 activates vacuolar V-ATPase to provide the driving force for $\mathrm{NHX1}$ and CAX1 to sequester $\mathrm{Na}^{+}$and $\mathrm{Ca}^{2+}$ respectively, also activated by CIPK24 (Cheng et al., 2004 ; Batelli et al., 2007; Quintero et al., 2011). 
Critically, hyperosmotic stress hyperpolarizes root epidermal PM voltage (Maathuis, 2014) and this would potentially be a basis for generating a component of the $\left[\mathrm{Ca}^{2+}\right]_{\text {cyt }}$ signal specific to the hyperosmotic component of $\mathrm{NaCl}$ stress.

\section{$\mathrm{Ca}^{2+}$ Influx across the PM}

Application of $\mathrm{NaCl}$ can cause a heterogeneous increase in Arabidopsis and rice root $\left[\mathrm{Ca}^{2+}\right]_{c y t}$ that depends on cell type, external $\left[\mathrm{Ca}^{2+}\right]$, and the bathing medium's effect on PM voltage (Kiegle et al., 2000; Tracy et al., 2008; Laohavisit et al., 2013; Choi et al., 2014; Zhang Y. et al., 2015). Pericycle cells of Arabidopsis have a lower amplitude of $\left[\mathrm{Ca}^{2+}\right]_{\text {cyt }}$ increase and a more variable recovery phase than the surrounding tissues (Kiegle et al., 2000), suggesting a cell-specific transporter complement. Block of NaCl-induced $\left[\mathrm{Ca}^{2+}\right]_{\text {cyt }}$ increase by lanthanides implicates $\mathrm{PM} \mathrm{Ca}^{2+}$ influx channels in the response of both Arabidopsis and rice roots (Tracy et al., 2008; Zhang Y. et al., 2015). The anti-apoptotic protein $\mathrm{Bcl}-2$ mimics lanthanides in that its overexpression impairs the $\mathrm{NaCl}$-induced $\left[\mathrm{Ca}^{2+}\right]_{\text {cyt }}$ increase in rice roots (Kim et al., 2014). Clearly, the $\left[\mathrm{Ca}^{2+}\right]_{\mathrm{cyt}}$ increase could lead to cell death if it were great enough and Bcl-2 may interact directly with PM channels. The genetic identities of the $\mathrm{PM} \mathrm{Ca}^{2+}$ influx channels initiating the $\mathrm{NaCl}$-induced $\left[\mathrm{Ca}^{2+}\right]_{\text {cyt }}$ increase remain unknown. It has been suggested that they may be $\mathrm{Ca}^{2+}$-permeable CNGCs (Shabala et al., 2015) as salinity stress increased cytosolic cGMP in Arabidopsis seedlings within seconds (Donaldson et al., 2004). The source of cGMP may prove to be critical as only the $\left[\mathrm{Ca}^{2+}\right]_{\text {cyt }}$ response to low $\mathrm{NaCl}(50 \mathrm{mM})$ was sensitive to inhibition of soluble guanylyl cyclase activity and the signal evoked by an equivalent osmotic stress was insensitive (Donaldson et al., 2004). It remains feasible that neither the ionic nor osmotic components of the $\left[\mathrm{Ca}^{2+}\right]_{\text {cyt }}$ increase in response to high $[\mathrm{NaCl}]$ require cGMP. The osmotic component of $\mathrm{NaCl}$ stress could increase $\left[\mathrm{Ca}^{2+}\right]_{\mathrm{cyt}}$ in Arabidopsis roots through the PM mechanosensitive $\mathrm{Ca}^{2+}$-permeable channel OSCA1 (Reduced Hyperosmolality-Induced $\left[\underline{\mathrm{Ca}}^{2+}\right]_{I}$ increase $\underline{1}$ ). This channel mediates the $\left[\mathrm{Ca}^{2+}\right]_{\text {cyt }}$ response to hyperosmotic stress (Yuan et al., 2014). Its discovery through a screen of aequorin-expressing mutants (Yuan et al., 2014) highlights the potential of this approach for identification of channels (and their families) involved in stress-induced $\left[\mathrm{Ca}^{2+}\right]_{c y t}$ elevation.

The initial increase in $\left[\mathrm{Ca}^{2+}\right]_{\text {cyt }}$ could be amplified by the production of ROS sourced ultimately by PM NADPH oxidases (encoded by Respiratory $\underline{B}$ urst $\underline{\text { Oxidase }} \underline{\text { Homolog genes), with }}$ $\left[\mathrm{Ca}^{2+}\right]_{\text {cyt }}$ activating these enzymes through their EF hands (Figure 2). In accordance with this, Arabidopsis root cortical cells lacking RBOHD and F have much lower PM hyperpolarizationactivated $\mathrm{Ca}^{2+}$ activity in response to $\mathrm{NaCl}$ challenge than wild type (Ma et al., 2012). Mutant seedlings have an impaired $\left[\mathrm{Ca}^{2+}\right]_{\text {cyt }}$ response. Arabidopsis $\mathrm{RBOHD}$ can be activated by CIPK26/CBL1/9 (Drerup et al., 2013) but a direct link to stress has not been shown. Extracellular hydroxyl radicals are likely to be the ROS involved in $\left[\mathrm{Ca}^{2+}\right]_{\text {cyt }}$ elevation (Chung et al., 2008; Demidchik et al., 2010; Laohavisit et al., 2013; Richards et al., 2015). The extracellular superoxide anions produced by NADPH oxidases are readily converted to $\mathrm{H}_{2} \mathrm{O}_{2}$ and wall $\mathrm{Fe} / \mathrm{Cu}$ act as Fenton catalysts to generate hydroxyl radicals (Richards et al., 2015). Their production by Arabidopsis roots is significantly increased under $\mathrm{NaCl}$ stress (Demidchik et al., 2010) and RBOHC is implicated as a driver for production (Chung et al., 2008). Extracellular hydroxyl radicals activate a $\mathrm{PM} \mathrm{Ca}{ }^{2+}$ influx in Arabidopsis root epidermis (Demidchik et al., 2003; Foreman et al., 2003) that has now been shown to be mediated by Annexin1 (Laohavisit et al., 2012).

Annexins are $\mathrm{Ca}^{2+}$-binding proteins that can bind to or insert into membranes and are implicated in stress reactions (Laohavisit and Davies, 2011; Davies, 2014). Critically, when root epidermal protoplasts are challenged with $\mathrm{NaCl}$, the resultant $\mathrm{PM}$ hyperpolarization-activated $\mathrm{Ca}^{2+}$ influx is lost in the annexin1 loss of function mutant and the $\left[\mathrm{Ca}^{2+}\right]_{\mathrm{cyt}}$ signal is impaired (Laohavisit et al., 2013). Hydroxyl radicals are potent but shortlived so their effects must be close to the site of production (Richards et al., 2015). As NADPH oxidases can be held in lipid rafts it may be that hydroxyl radicals target co-resident channels. Finally, extracellular ATP levels of Arabidopsis roots increase in response to $\mathrm{NaCl}$ (Dark et al., 2011). Extracellular ATP activates root epidermal PM hyperpolarization-activated $\mathrm{Ca}^{2+}$ influx channels via RBOHC (Demidchik et al., 2009), suggesting the involvement of extracellular ROS in channel activation. Whether these channels involve Annexin1 remains to be determined but both the annexin 1 and rbohc loss of function mutants are impaired in $\left[\mathrm{Ca}^{2+}\right]_{c y t}$-dependent transcriptional responses under $\mathrm{NaCl}$ stress (Chung et al., 2008; Laohavisit et al., 2013).

\section{Calcium Release from Stores}

Although not demonstrated in roots, the Arabidopsis ActinRelated Protein2/3 (ARP2/3) acts to limit NaCl-induced $\left[\mathrm{Ca}^{2+}\right]_{c y t}$ increase, partly by limiting $\mathrm{Ca}^{2+}$ release from mitochondria. In the $\operatorname{arp} 2 / 3$ mutant, the $\left[\mathrm{Ca}^{2+}\right]_{c y t}$ increase is greater than wild type and so is the extent of mitochondrialdriven cell death (Zhao et al., 2013). Release of vacuolar $\mathrm{Ca}^{2+}$ to the cytosol in Arabidopsis roots may be by a Na${ }^{+} / \mathrm{Ca}^{2+}$ exchanger encoded by AtNCL ( $\mathrm{Na}^{+} / \mathrm{Ca}^{2+}$ Exchanger-Like; Wang et al., 2012; Li P.H. et al., 2016). This tonoplast protein is thought to sequester $\mathrm{Na}^{+}$into the vacuole, coupled to the release of vacuolar $\mathrm{Ca}^{2+}$. The concomitant increase in $\left[\mathrm{Ca}^{2+}\right]_{\text {cyt }}$ could provide a negative feedback mechanism to limit further transport as $\mathrm{Ca}^{2+}$ binding to the exchanger's $\mathrm{EF}$ hands has been shown to be inhibitory in vitro (Li P.H. et al., 2016). Pharmacological approaches have also implicated internal stores in the $\mathrm{NaCl}$ induced $\left[\mathrm{Ca}^{2+}\right]_{\text {cyt }}$ increase in roots of both Arabidopsis and rice. Inhibitors of store release of $\mathrm{Ca}^{2+}$ by cADPR (cyclic ADP ribose) and inositol trisphosphate $\left(\mathrm{Ins}_{3}\right)$ suggested involvement of the InsP $\mathrm{P}_{3}$ pathway in Arabidopsis roots (Tracy et al., 2008). Moreover, salt and hyperosmotic stress in Arabidopsis roots caused an InsP $\mathrm{P}_{3}$ accumulation that correlated well with $\left[\mathrm{Ca}^{2+}\right]_{\text {cyt }}$ increase (DeWald et al., 2001). The rice $\left[\mathrm{Ca}^{2+}\right]_{\text {cyt }}$ signal was also sensitive to disruption of putative $\mathrm{InsP}_{3}$-gated store release whilst impairment by thapsigargin implicated the ER as a participating store (Zhang Y. et al., 2015). However, using ER-targeted YC3.6, Bonza et al. (2013) detected an increase in Arabidopsis root ER $\left[\mathrm{Ca}^{2+}\right]$ in response to salt stress. This followed the salt-induced $\left[\mathrm{Ca}^{2+}\right]_{c y t}$ increase and critically, a drop in ER $\left[\mathrm{Ca}^{2+}\right]$ prior to 
the $\left[\mathrm{Ca}^{2+}\right]_{\text {cyt }}$ increase was never observed. Therefore, with the level of resolution available, it appears that in this system the ER does not contribute to the $\left[\mathrm{Ca}^{2+}\right]_{\text {cyt }}$ signal through store release but acts to return $\left[\mathrm{Ca}^{2+}\right]_{\text {cyt }}$ to resting levels. Studies on Populus euphratica cultured cells identified the vacuole as the site of InsP $\mathrm{P}_{3}$ and cADPR action (Zhang X. et al., 2015). Certainly, Phospholipase $\mathrm{C}$ isoforms (as the source of $\mathrm{InsP}_{3}$ ) are firmly implicated in salt stress responses (reviewed by Ruelland et al., 2015).

The genetic identities of the endomembrane $\mathrm{Ca}^{2+}$-permeable channels implicated by pharmacological studies remain elusive. GLRs have recently been postulated to be involved in $\mathrm{ER} \mathrm{Ca}^{2+}$ release (Weiland et al., 2016). The TPC1 vacuolar channel of Arabidopsis would be capable of releasing $\mathrm{Ca}^{2+}$ to the cytosol and recent analyses of its crystal structure has thrown greater light on its regulation by voltage and EF hands (Guo et al., 2016; Kintzer and Stroud, 2016). At current resolution afforded by YC3.6, its loss does not appear to have a significant impact on the magnitude of the Arabidopsis root $\left[\mathrm{Ca}^{2+}\right]_{\text {cyt }}$ increase to salt, rather it slightly delays the response (Choi et al., 2014). However, TPC1 has a significant part to play in the propagation of a $\left[\mathrm{Ca}^{2+}\right]_{\text {cyt }}$ wave that travels from the root apex through the cortical and endodermal tissue to signal the $\mathrm{NaCl}$ challenge to the shoots and elicit a transcriptional response. ROS also relay a salinity stress signal (reliant on RBOHD) in Arabidopsis leaves (Miller et al., 2009) but whether this occurs in roots and is involved in propagating the $\left[\mathrm{Ca}^{2+}\right]_{\text {cyt }}$ wave remains to be tested.

\section{Decoding, $\mathrm{Na}^{+}$Clearance, Transcription and the Unfolded Protein Response}

Salinity-induced $\left[\mathrm{Ca}^{2+}\right]_{\text {cyt }}$ elevation in roots drives a transcriptional response (Laohavisit et al., 2013; Zhang Y. et al., 2015) and post-translational modifications. The proteins sensing the $\mathrm{NaCl}$-induced $\left[\mathrm{Ca}^{2+}\right]_{\text {cyt }}$ increase are now being elucidated. For example, the Arabidopsis vacuolar Two Pore $\mathrm{K}^{+}$ channel 1 (TPK1) would bind $\mathrm{Ca}^{2+}$, and open to release $\mathrm{K}^{+}$to the cytosol to maintain a favorable $\mathrm{Na}^{+} / \mathrm{K}^{+}$ratio (Latz et al., 2013). This could be further enhanced by phosphorylation by $\mathrm{CPK} 3$, which requires micromolar $\left[\mathrm{Ca}^{2+}\right]$ for activity. CPK3 is present at both the PM and vacuole. It does not appear to contribute to a transcriptional response under salt stress but has a discrete set of protein targets to phosphorylate (Mehlmer et al., 2010). On prolonged salt stress, CPK29 expression is induced. This protein can phosphorylate TPK1 at sub-micromolar $\left[\mathrm{Ca}^{2+}\right]$ and is envisaged to be part of longer-term $\mathrm{K}^{+}$homeostasis in adapted roots (Latz et al., 2013). Also in Arabidopsis, CPK27 (present at the root PM) acts to promote $\mathrm{Na}^{+}$efflux (Zhao et al., 2015). Intriguingly, CPK7 acts to limit water transport in Arabidopsis roots through lowering PIP1 aquaporin abundance (Li et al., 2015) but whether this is relevant to salinity or osmotic stress is not yet known. It can be readily envisaged that calmodulins will bind $\mathrm{Ca}^{2+}$ and as these are negative regulators of CNGC channels (Hua et al., 2003), would act to limit further $\mathrm{Na}^{+}$or $\mathrm{Ca}^{2+}$ influx at the PM. Further, CaM activation of ACAs (Autoinhibited $\underline{\mathrm{Ca}}^{2+}$ ATPases) would restore $\left[\mathrm{Ca}^{2+}\right]_{\text {cyt }}$ to pre-stimulus levels (Boursiac and Harper, 2007). Expression of ACAs varies with salt stress and, as shown by rice roots, can relate to salt tolerance (Yamada et al., 2014).

The Salt Overly Sensitive (SOS) pathway lies downstream of the root $\left[\mathrm{Ca}^{2+}\right]_{\text {cyt }}$ increase. Delineated in Arabidopsis and now acknowledged as operating in crops and trees (ThodayKennedy et al., 2015), the SOS pathway leads to $\mathrm{Na}^{+}$efflux from the cytosol. Efflux across the PM is mediated by the SOS1 $\mathrm{Na} / \mathrm{H}^{+}$antiporter. Salt stress induction of SOS1 transcription lies downstream of Annexin1 in Arabidopsis roots and as SOS1 is required for adaptive adventitious root formation, the annexin1 loss of function mutant accordingly produces fewer of these than wild type (Laohavisit et al., 2013). Additionally, the stability of salt stress-induced SOS1 transcript requires RBOHC (Chung et al., 2008), further suggesting that this NADPH oxidase and Annexin1 may be in the same pathway. In Arabidopsis roots, increased $\left[\mathrm{Ca}^{2+}\right]_{\text {cyt }}$ is sensed at the PM by CBL4 (SOS3) which can then react with the serine/threonine protein kinase CIPK24 (SOS2) (Liu et al., 2000). The resultant CBL/CIPK complex phosphorylates the $\mathrm{PM} \mathrm{Na} / \mathrm{H}^{+}$antiporter SOS1 at its auto-inhibitory C-terminus to achieve activation of $\mathrm{Na}^{+}$efflux (Quintero et al., 2011). Activation of SOS1 can also be achieved in Arabidopsis by Mitogen Activated Protein Kinase6 (MPK6) and loss of MPK6 function impairs root growth under salt stress (Yu et al., 2010). MPK6 is activated by a phosphatidic acid produced under salt stress by Phospholipase D $\alpha 1$ (PLD $\alpha 1$ ) (Yu et al., 2010). As this PLD isoform contains a $\mathrm{Ca}^{2+}$-binding $\mathrm{C} 2$ domain for its activation it is feasible that salt-induced $\left[\mathrm{Ca}^{2+}\right]_{\text {cyt }}$ increase could activate SOS1 through this lipid-mediated pathway via MPK6 (Yu et al., 2015). This may help explain the importance of activation of PLDs in salt-stressed crop roots such as barley (Meringer et al., 2016). SOS2 may also promote activity of the vacuolar V-type $\mathrm{H}^{+}$-ATPase to provide the driving force for $\mathrm{Na}^{+}$ sequestration (Batelli et al., 2007). The $\mathrm{NHX} 1 \mathrm{Na}^{+}-\mathrm{H}^{+}$exchanger may also be regulated by SOS2 to aid vacuolar $\mathrm{Na}^{+}$sequestration (Qiu et al., 2004) and SOS2 activation of the vacuolar CAX1 $\mathrm{Ca}^{2+} / \mathrm{H}^{+}$antiporter would help terminate a $\left[\mathrm{Ca}^{2+}\right]_{\text {cyt }}$ signature through $\mathrm{Ca}^{2+}$ sequestration (Cheng et al., 2004). Other CAX are involved in root tolerance of salt stress and the pathways to their induction and regulation now need to be identified (Yamada et al., 2014).

Salt exposure puts the plant's ER under stress, leading to an accumulation of unfolded or misfolded proteins that could lead to cell death (Liu et al., 2007, 2011). Such ER stress triggers upregulation of a suite of responses termed the "Unfolded Protein Response" (UPR), in which folding capacity is upregulated (including by $\mathrm{Ca}^{2+}$-regulated chaperones), translation is curtailed and the ER-associated degradation pathway acts to lower the aberrant protein load (Deng et al., 2013; Ruberti et al., 2015; Hossain et al., 2016; Wan and Jiang, 2016). Expression of the ER $\mathrm{Ca}^{2+}$-binding chaperones Calnexin and Calreticulin has been shown to upregulated in the Arabidopsis UPR (Christensen et al., 2008; Liu et al., 2011) and it would now be interesting to test whether these are involved in regulating levels of $\mathrm{Ca}^{2+}$ in the ER under stress. However, expression of rice's only calnexin gene is decreased under salt stress (Sarwat and Naqvi, 2013). It is not yet clear whether the salt-induced $\left[\mathrm{Ca}^{2+}\right]_{\text {cyt }}$ signal in roots (or other parts 
of the plant) helps initiate or regulate the UPR. It is feasible that the salt-induced $\left[\mathrm{Ca}^{2+}\right]_{c y t}$ increase activates the root PM Phospholipase C2 (Hunt et al., 2004) because the Arabidopsis loss of function mutant is hypersensitive to tunicamycin, which can induce the UPR (Kanehara et al., 2015). With $\mathrm{IP}_{3}$ as the product of Phospholipase $\mathrm{C}$ activity, this would implicate $\mathrm{IP}_{3}$ mediated release of $\mathrm{Ca}^{2+}$ from stores. Indeed, for Arabidopsis seedlings the application of 2-aminoethoxydiphenyl borate as an inhibitor of $\mathrm{IP}_{3}$-mediated $\mathrm{Ca}^{2+}$ release prevented salt stressinduced transcription of BIP1/2 (encoding an ER chaperone) as a diagnostic of a UPR response (Liu et al., 2011). Intriguingly, application of $\mathrm{La}^{3+}$ as a blocker of $\mathrm{PM} \mathrm{Ca}{ }^{2+}$ influx prevented the upregulation of UPR gene expression which was produced by application of spermine to Arabidopsis seedlings (Sagor et al., 2015). Exogenous spermine (as with salt) can depolarise the root epidermal PM (Pottosin et al., 2014) and can also attenuate hydroxyl radical-induced cation fluxes at root epidermal PM (Zepeda-Jazo et al., 2011). Whether spermine and salt stress share a common pathway to the UPR response merits further investigation.

\section{WATER AVAILABILITY IS SIGNALED THROUGH $\left[\mathrm{Ca}^{2+}\right]_{\text {cyt }}$}

The hyperosmotic challenge in $\left[\mathrm{Ca}^{2+}\right]_{\text {cyt }}$ determinations is acute and does not mimic the chronic, progressive drought conditions that roots may face. Nevertheless, such studies have proved fruitful. As described above, the Arabidopsis OSCA1 PM Ca ${ }^{2+}$ influx channel drives the root's initial hyperosmotic stress $\left[\mathrm{Ca}^{2+}\right]_{\text {cyt }}$ signal (Yuan et al., 2014). In an elegant study, heterologous expression of Arabidopsis genes in Chinese Hamster Ovary $(\mathrm{CHO})$ cells containing the Fura- $2 \mathrm{Ca}^{2+}$-reporting dye lead to the identification of Calcium-permeable Stress-gated

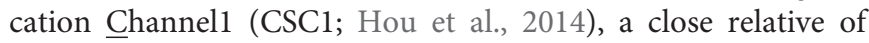
OSCA1. CSC1 has been characterized in $\mathrm{CHO}$ cells as a PM $\mathrm{Ca}^{2+}$-permeable channel that is activated by hyperosmotic stress. It is resident in plant PM (Hou et al., 2014) and is expressed in roots but to date an in planta role remains unreported. Targeting aequorin to the cytosolic face of the Arabidopsis vacuolar membrane has revealed the capacity of the vacuole to release $\mathrm{Ca}^{2+}$ in response to acute hyperosmotic stress, with pharmacological intervention suggesting an involvement of InsP $\mathrm{P}_{3}$ (Knight et al., 1997). As with salt stress, hyperosmotic stress-induced $\left[\mathrm{Ca}^{2+}\right]_{\text {cyt }}$ increase could activate Phospholipases and initiate lipid signaling. Osmotic stress activates PLD in barley roots (Meringer et al., 2016). Although not tested directly, phosphatidic acid downstream of PLD could be involved in the activation of two sucrose non-fermenting-1 related protein kinase 2 proteins (SnRK2.4 and 2.10) in Arabidopsis roots under hyperosmotic stress. These SnRK2s are also activated under salt stress and relocate from the root epidermal cytosol to the PM; loss of function impairs root growth (McLoughlin et al., 2012). Work using Golgi-targeted aequorin in Arabidopsis seedlings has shown that an increase in Golgi $\left[\mathrm{Ca}^{2+}\right]$ follows the $\left[\mathrm{Ca}^{2+}\right]_{\text {cyt }}$ increase induced by hyperosmotic stress, suggesting that this organelle helps terminate the $\left[\mathrm{Ca}^{2+}\right]_{\text {cyt }}$ signal (Ordenes et al., 2012).
The ABA produced under drought stress inhibits primary root growth and $\left[\mathrm{Ca}^{2+}\right]_{\text {cyt }}$ is likely to play a role in the signaling pathway as exogenous ABA elevates root $\left[\mathrm{Ca}^{2+}\right]_{\text {cyt }}$, which in Arabidopsis roots is controlled by the PM Proline-rich Extensinlike Receptor Kinase4 (PERK4) (Bai et al., 2009). PERK4's extracellular domain is wall associated and its intracellular domain has kinase activity. PM HACCs lie downstream of ABA and PERK4. The perk4 mutant is not only impaired in ABAinduced HACC activity and $\left[\mathrm{Ca}^{2+}\right]_{\text {cyt }}$ activation but also in ABA inhibition of primary root elongation (Bai et al., 2009). This implies that $\left[\mathrm{Ca}^{2+}\right]_{\text {cyt }}$ elevation acts to arrest growth. RBOHD/F may lie downstream of PERK4 and upstream of HACCs in the root ABA pathway if the HACCs were ROS-activated. The rbohd/f mutant is impaired in both ABA-induced HACC activation and $\left[\mathrm{Ca}^{2+}\right]_{\text {cyt }}$ elevation (Jiao et al., 2013). Another possibility is that CNGCs are involved as ABA can increase cGMP levels (Isner et al., 2012.). GLRs are firmly implicated in the drought response; overexpression of rice GLR1 and GLR2 enhances drought tolerance of both rice and Arabidopsis ( $\mathrm{Lu}$ et al., 2014). The $\left[\mathrm{Ca}^{2+}\right]_{\text {cyt }}$ increase is likely to lead to a transcriptional response as $\mathrm{Ca}^{2+}$-sensing proteins are activated. ABA increases abundance and activity of Arabidopsis CPK4 and CPK11 leading to phosphorylation of the ABA-responsive transcription factors $\mathrm{ABF} 1$ and $\mathrm{ABF} 4$ and induction of drought stress genes (Zhu et al., 2007). Drought leads to CAMTA1 activity and the regulation of discrete gene sets including those for drought recovery (Pandey et al., 2013). In maize roots, drought stress triggers activity of CIPK8 (which interacts with CBL1, 4, and 9) and likely leads to adaptive transcription (Tai et al., 2016).

Hypoosmotic stress also elevates $\left[\mathrm{Ca}^{2+}\right]_{\text {cyt }}$ and is relevant to waterlogged soils. In Arabidopsis, root PM harbors two mechanosensitive $\mathrm{Ca}^{2+}$-permeable channels, MCA1 and MCA2 (Mid1-Complementing Activity; Kamano et al., 2015). MCA1 responds to hypoosmotic stress to elevate $\left[\mathrm{Ca}^{2+}\right]_{\text {cyt }}$ (Nakagawa et al., 2007). Rice only harbors an MCA1 in the PM. It is present in the root and mediates hypoosmotic shock-induced $\left[\mathrm{Ca}^{2+}\right]_{\text {cyt }}$ expression in cultured cells, probably lying upstream of NADPH oxidase activity (Kurusu et al., 2012). Abundant water not only exposes roots to potential hypoosmotic stress but also risks limiting their oxygen supply, the consequences of which are reviewed in the following section.

\section{MECHANISTIC BASIS OF $\left[\mathrm{CA}^{2+}\right]_{\text {cyt }}$ RESPONSE TO $\mathrm{O}_{2}$ DEFICIENCY REMAINS POORLY UNDERSTOOD}

Oxygen deficiency (hypoxia) or absence (anoxia) causes transient increases in root $\left[\mathrm{Ca}^{2+}\right]_{\text {cyt }}$ but the signature is organ- and species-dependent (reviewed by Shabala et al., 2014). For example, when challenged by anoxia, root protoplasts from hypoxia-tolerant rice display a greater $\left[\mathrm{Ca}^{2+}\right]_{\text {cyt }}$ signature than hypoxia-intolerant wheat root protoplasts (Yemelyanov et al., 2011). The location of the $\mathrm{Ca}^{2+}$ influx also varies; use of pharmacological blockers showed that the rice signature was generated by both PM influx and store release whilst wheat 
appeared to rely solely on stores (Yemelyanov et al., 2011). The types of $\mathrm{Ca}^{2+}$ channels mediating the $\left[\mathrm{Ca}^{2+}\right]_{\text {cyt }}$ increase have yet to be identified in any species. However, those activated by PM voltage depolarization are implicated. As $\mathrm{O}_{2}$ deficiency lessens ATP production, activity of the $\mathrm{PM} \mathrm{H}^{+}$ATPase can be compromised thus resulting in a less negative (depolarized) $\mathrm{PM}$ voltage as $\mathrm{H}^{+}$efflux is curtailed. The extent and duration of membrane depolarization varies with sensitivity to $\mathrm{O}_{2}$ deprivation and cell type. Values of -70 to $-80 \mathrm{mV}$ have been reported for $\mathrm{O}_{2}$-deprived barley root cells (Zeng et al., 2014) and theoretically these would be sufficient to activate PM depolarization-activated $\mathrm{Ca}^{2+}$ influx channels (Miedema et al., 2008) to contribute to an hypoxia/anoxia $\left[\mathrm{Ca}^{2+}\right]_{\text {cyt }}$ signature. Downstream of the $\left[\mathrm{Ca}^{2+}\right]_{\text {cyt }}$ signature, it is likely that CaM and ROPs (Rho GTPase) are activated (reviewed by Shabala et al., 2014). In Arabidopsis roots, hypoxia causes rapid upregulation of CML38 expression and this protein appears to require $\mathrm{Ca}^{2+}$ to associate with the cytosolic stress granules that form and store messenger RNA ribonucleoproteins (Lokdarshi et al., 2016).

$\mathrm{RBOH}$ activity is firmly implicated in the response to low $\mathrm{O}_{2}$. In Arabidopsis, $\mathrm{RBOHD}$ expression is induced by hypoxia and is required for transcription of hypoxia-induced genes (Yang and Hong, 2015). Hypoxia also induces ethylene production and in wheat roots this causes $\mathrm{RBOH}$ induction (Yamauchi et al., 2014). A further level of regulation has been found in Arabidopsis; the Hypoxia Responsive Universal Stress Protein 1 (HRU1) interacts with GTP-bound ROP2 and RBOHD (Gonzali et al., 2015). HRU1 is one of 44 putative universal stress proteins in Arabidopsis. It exists as a cytosolic dimer but anoxia promotes monomer formation and increased association with the PM. There it is thought to be part of a mobile complex with ROP2 and AtRBOHD leading to activation of that NADPH oxidase (Gonzali et al., 2015). Although $\mathrm{RBOH}$ activity has been linked to $\mathrm{PM} \mathrm{Ca}^{2+}$ channel activation in several abiotic stress scenarios, hypoxia and anoxia have yet to be tested.

Ethylene has been shown to activate $\mathrm{PM} \mathrm{Ca}{ }^{2+}$-permeable channels (with a weak voltage dependence) in tobacco suspension cells (Zhao et al., 2007) and it remains a possibility that these may play a part in the root hypoxia $\left[\mathrm{Ca}^{2+}\right]_{\text {cyt }}$ signal with $\mathrm{RBOH}$ as an intermediary. Oxygen deprivation (and also sulfur and phosphate, $\mathrm{Pi}$, deprivation) triggers programmed cell death (PCD) in mid-cortical cells for aerenchyma formation (Fagerstedt, 2010). This PCD is stimulated by ethylene and ROS and involves $\mathrm{Ca}^{2+}$ (Xu et al., 2013; Petrov et al., 2015). In wheat roots, anoxia causes mitochondria to release their $\mathrm{Ca}^{2+}$ and high $\left[\mathrm{Ca}^{2+}\right]_{\text {cyt }}$ causes cytochrome $\mathrm{c}$ release (Virolainen et al., 2002). The abnormal mitochondrial ultrastructure in Arabidopsis caused by hypoxia is partially phenocopied by loss of GLR3.5 from the inner mitochondrial membrane, suggesting that this channel must be deactivated during PCD (Teardo et al., 2015). Further channels must now be identified to understand the hypoxic/anoxic response. Recent work on Arabidopsis roots has shown distinct, cell-specific levels of $\left[\mathrm{Ca}^{2+}\right]_{\text {cyt }}$ after $24 \mathrm{~h}$ of hypoxia and highlighted the importance of CAX11 in controlling meristem $\left[\mathrm{Ca}^{2+}\right]_{\text {cyt }}$ (Wang et al., 2016). Loss of CAX4 function resulted in lower tolerance of hypoxia thus further demonstrating the importance of $\mathrm{Ca}^{2+}$ sequestration in this stress response (Wang et al., 2016).

\section{$\mathrm{CA}^{2+}$ SIGNALING IN NUTRIENT DEPRIVATION IS AN EMERGING AREA}

Investigating $\left[\mathrm{Ca}^{2+}\right]_{\text {cyt }}$ elevation in response to nutrient deprivation or resupply is technically challenging, particularly if using aequorin. Nevertheless it is now clear that nutrient levels can induce $\left[\mathrm{Ca}^{2+}\right]_{\text {cyt }}$ changes and that downstream $\mathrm{Ca}^{2+}$ sensors regulate appropriate responses. The nutritional status of the root will have a part to play in determining the $\left[\mathrm{Ca}^{2+}\right]_{\text {cyt }}$ signatures, particularly of the endodermis as the extent of suberization is set by nutrition (Barberon et al., 2016) and suberin lamellae determine endodermal $\left[\mathrm{Ca}^{2+}\right]_{\text {cyt }}$ responses (Moore et al., 2002). To date, potassium, nitrate and boron have been studied.

\section{Potassium}

Plants must maintain cytosolic $\mathrm{K}^{+}$at around $80 \mathrm{mM}$ for optimal growth even though soil concentration may be submillimolar and they deploy a multigene family of $\mathrm{K}^{+}$transporters in homeostatic control (Shabala and Pottosin, 2014). As extracellular $\mathrm{K}^{+}$decreases, the root epidermal PM hyperpolarizes and $\left[\mathrm{Ca}^{2+}\right]_{\text {cyt }}$ increases (Demidchik et al., 2002). This increase can be abolished by gadolinium, implicating $\mathrm{PM} \mathrm{Ca}{ }^{2+}$ influx.

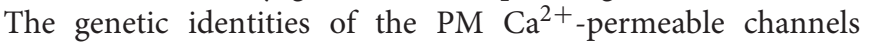
that would effect the $\left[\mathrm{Ca}^{2+}\right]_{c y t}$ increase remain unknown. The hyperpolarised PM correlates with induction of HAK5 expression in tomato root (Nieves-Cordones et al., 2008). HAK5 encodes the PM High Affinity $\underline{\mathrm{K}}^{+}$transporter that facilitates $\mathrm{K}^{+}$uptake from low external concentrations that are thermodynamically unfavorable for channel-mediated influx. In Arabidopsis roots, low $\mathrm{K}^{+}$-induction of HAK5 expression (and other $\mathrm{K}^{+}$-deprivation genes) has been shown to depend on RBOHC activity and ROS (Shin and Schachtman, 2004). At present it is unclear whether the hyperpolarization of the PM directly activates RBOHC (which as an electron exporter may be voltage-dependent) or whether ROS-activated $\mathrm{PM} \mathrm{Ca}^{2+}$ channels are involved in the $\mathrm{K}^{+}$-deprivation $\left[\mathrm{Ca}^{2+}\right]_{\text {cyt }}$ signal. HAK5 activity in Arabidopsis roots is regulated by CIPK23-mediated phosphorylation, downstream of CBL1, CBL8, CBL9, and CBL10 (Ragel et al., 2015). The extent to which the transcriptional response to low $\mathrm{K}^{+}$availability is governed by $\left[\mathrm{Ca}^{2+}\right]_{\text {cyt }}$ is unclear but deficiency does result in upregulation of transcripts of $\mathrm{Ca}^{2+}$ signaling proteins (CaM, CBL, CIPK) in Arabidopsis seedlings (Armengaud et al., 2004) and sugarcane roots (Zeng et al., 2015). At higher external $\left[\mathrm{K}^{+}\right]$, the AKT1 channel ( $\underline{\text { Arabidopsis }} \underline{\mathrm{K}}^{+}$ Transporter1) facilitates uptake and its activity is promoted by CIPK23-mediated phosphorylation, downstream of CBL1 and CBL9 (Li et al., 2006; Cheong et al., 2007). This regulation is recapitulated in rice roots where CIPK23/CBL1 activate AKT1 (Li et al., 2014).

\section{Nitrate}

Nitrate is the most important form of nitrogen for agriculture and deprivation triggers significant transcriptional and 
developmental responses. The effect of nitrate withdrawal on $\left[\mathrm{Ca}^{2+}\right]_{\text {cyt }}$ has yet to be reported but recently it was shown that nitrate-starved Arabidopsis roots responded to nitrate resupply with a rapid, monophasic transient increase in $\left[\mathrm{Ca}^{2+}\right]_{\text {cyt }}$ that was sensitive to lanthanides and phospholipase C (PLC) inhibition (Riveras et al., 2015). Lanthanum also blocked nitrate-induced Ins $\mathrm{P}_{3}$ production, suggesting that $\mathrm{Ca}^{2+}$ influx across the $\mathrm{PM}$ activated a PLC. The $\left[\mathrm{Ca}^{2+}\right]_{\text {cyt }}$ and $\mathrm{InsP}_{3}$ increases were entirely dependent on the PM nitrate influx transporter NRT1.1 (Nitrate Transporter1.1; Riveras et al., 2015). By using the nrt1.1 mutant and pharmacological blockers, nitrate-induced gene transcription was also found to lie downstream of NRT1.1, and $\left[\mathrm{Ca}^{2+}\right]_{\text {cyt }}$ elevation from PM influx and $\mathrm{InsP}_{3}$-gated store release. Calcium is also key to the regulation of nitrate uptake capacity as CIPK23, which is activated by CBL9 and CBL1, and dephosphorylated by ABI2 (a member of the PP2C protein phosphatase family; Léran et al., 2015,), phosphorylates NRT1.1 under low nitrate condition, thus converting it from a low to high affinity transporter (Ho et al., 2009). By contrast CIPK8 positively regulates the low-affinity phase of the nitrate primary response which includes transcriptional regulation, but its regulation of primary root elongation is concentration independent in Arabidopsis (Hu et al., 2009). CBL7, which is upregulated under nitrate deprivation, positively regulates the nitrate-dependent induction of NTR2.4 and NTR2.5 gene expression (Ma Q. et al., 2015). Given the lack of a $\left[\mathrm{Ca}^{2+}\right]_{\text {cyt }}$ reporter line available in crops up until recently for rice, little is known about nitrate deficiency-induced $\left[\mathrm{Ca}^{2+}\right]_{\text {cyt }}$ signaling but $\mathrm{CaM}$ protein abundance of wheat roots declines under nitrate deficiency, suggesting a remodeling of signaling systems (Jiang et al., 2015).

\section{Boron}

Boron deficiency is widespread worldwide and particularly prevalent in China (Shorrocks, 1997). As B plays a dominant role in co-ordinating cell wall structure (Kobayashi et al., 1996), changes in cell wall stability are likely to influence the signal relayed into the cell upon $\mathrm{B}$ deprivation and indeed a rapid change in cell wall modulus has been observed (Goldbach et al., 2001). Early work in Vicia faba showed a release of membranebound $\mathrm{Ca}^{2+}$ into the apoplast (Mühling et al., 1998), raising the possibility of $\mathrm{Ca}^{2+}$ signaling during the early stages of $\mathrm{B}$ deficiency. Increased levels of both $\left[\mathrm{Ca}^{2+}\right]_{\text {cyt }}$ and ROS have been suggested to lead to the increased root hair growth known to occur under B deprivation (González-Fontes et al., 2016). In cultured tobacco cells, transcriptional changes in response to short-term B deprivation ( $1 \mathrm{~h}$ ) were abolished when withdrawing $\mathrm{Ca}^{2+}$ from the growth medium or upon treatment with the $\mathrm{Ca}^{2+}$ channel blocker lanthanum, thus implicating $\mathrm{PM} \mathrm{Ca}^{2+}$ influx channels in generating a $\left[\mathrm{Ca}^{2+}\right]_{\text {cyt }}$ signal (Koshiba et al., 2010). However, a transient $\left[\mathrm{Ca}^{2+}\right]_{c y t}$ signal in direct response to $\mathrm{B}$ withdrawal has yet to be reported. Rather, work has focused on the possible remodeling of $\mathrm{Ca}^{2+}$ transport and signaling as a consequence of $\mathrm{B}$ deprivation.

Challenging cultured tobacco cells with $\mathrm{Ca}^{2+}$ resulted in a higher amplitude of $\left[\mathrm{Ca}^{2+}\right]_{\text {cyt }}$ transient in B-deprived cells ( $1 \mathrm{~h}$ deprivation) than those grown under replete conditions
(Koshiba et al., 2010). This suggests that B deprivation rapidly "resets" the $\mathrm{PM}^{\prime} \mathrm{Ca}^{2+}$ transport systems to generate altered $\left[\mathrm{Ca}^{2+}\right]_{\text {cyt }}$ responses. The $\left[\mathrm{Ca}^{2+}\right]_{\text {cyt }}$ response of $\mathrm{B}$-deprived cells was sensitive to lanthanum and diphenyleneiodonium, pointing to the involvement of $\mathrm{PM} \mathrm{Ca}{ }^{2+}$ channels and NADPH oxidases respectively (Koshiba et al., 2010). Arabidopsis roots expressing the YC3.6 $\left[\mathrm{Ca}^{2+}\right]_{\text {cyt }}$ reporter exhibited higher levels of $\left[\mathrm{Ca}^{2+}\right]_{\text {cyt }}$ at the apex than controls after 6 and $24 \mathrm{~h}$ of $\mathrm{B}$ deprivation (Quiles-Pando et al., 2013). This time course of B deprivation also resulted in significant upregulation of CNGC19 (encoding a vacuolar channel), four genes of the ACA family of $\mathrm{P}_{I I B}$-type $\mathrm{Ca}^{2+}$-ATPases $(A C A 1,10,12,13)$ and $C A X 3$ encoding a vacuolar cation- $\mathrm{H}^{+}$antiporter (Quiles-Pando et al., 2013). This suite of transporters could effect $\mathrm{Ca}^{2+}$ efflux from the vacuole (CNGC19) to increase $\left[\mathrm{Ca}^{2+}\right]_{\text {cyt }}$ with clearance to the apoplast by ACA1013 and sequestration to the vacuole by CAX3. How they are regulated remains to be determined, as does the involvement of the structurally compromised wall and the consequence of this higher level of apical $\left[\mathrm{Ca}^{2+}\right]_{c y t}$. The area of higher $\left[\mathrm{Ca}^{2+}\right]_{\mathrm{cyt}}$ reported appears to correspond with the zone of inhibition of primary root elongation and the induction of cell death (Oiwa et al., 2013; Camacho-Cristobal et al., 2015). Once again, ethylene production appears to be upstream of NADPH oxidase-driven ROS production in growth arrest and death (Oiwa et al., 2013; Camacho-Cristobal et al., 2015).

Eight $C M L$ genes were also significantly upregulated after a day's B deprivation of Arabidopsis roots (CML11,12,23,24, $30.37,45.47)$, as were three $C P K$ genes $(C P K 1,28,29)$ all suggesting a distinct change in intracellular $\mathrm{Ca}^{2+}$ signaling (Quiles-Pando et al., 2013). This B deprivation also caused upregulation of WRKY transcription factors (TF) (WRKY38,40,46), two three MYB family TF $(M Y B 14,15,78)$ and downregulation of two BZIP family TFs (bZIP34,61) (González-Fontes et al., 2016). B deprivation has also been found to promote the senescence-associated WRKY6 TF in the root tip (Kasajima et al., 2010). It has been suggested that the CMLs and $C P K$ s upregulated by $\mathrm{B}$ deprivation are part of the chain of events leading to TF activation in the nucleus (González-Fontes et al., 2016) and this now requires direct testing. CIPK8 also positively regulates nitrate induced up-regulation of BOR1, a gene encoding a boron transporter responsible for xylem loading (Hu et al., 2009), suggesting that root signaling results in preservation of shoot B supply.

\section{HEAVY METAL STRESS HAS THE CAPACITY TO DISTORT $\mathrm{Ca}^{2+}$ SIGNALING}

At the opposite end of nutritional deprivation is heavy metal stress. Industrial activity, mining and modern agricultural practices can lead to soil contamination by heavy metals (defined here as $7 \mathrm{~g} / \mathrm{cm}^{3}$ and above). Although some of these metals (such as $\mathrm{Zn}, \mathrm{Cu}$ ) are required as micronutrients they can be damaging in excess whilst others (such as $\mathrm{Cd}$ ) have no physiological role and can be deleterious even at low concentrations, often impairing mineral nutrition. The consequences of heavy metal 
exposure have been reviewed recently by Singh et al. (2016) and these authors explore signaling pathways (although not explicitly addressing $\mathrm{Ca}^{2+}$ ), intersects with hormonal responses and detoxification.

\section{Cadmium}

Cadmium is a particular threat to $\mathrm{Ca}^{2+}$-based processes because of its similar size. A recent review by Chmielowska-Bak et al. (2014) summarized the effects of Cd on ROS accumulation, NO accumulation, MAP kinase activation and downstream responses in a wide range of plant systems and, importantly, did this as a function of Cd exposure. With regards to $\mathrm{Ca}^{2+}$ a key question is whether $\mathrm{Cd}$ (as a $\mathrm{Ca}^{2+}$ "substitute") generates a signal in its own right or whether its impairment of $\mathrm{Ca}^{2+}$ homeostasis will be, in effect, the signal. Certainly $\mathrm{Cd}$ depolarises the rice root epidermal $\mathrm{PM}$, which would impair $\mathrm{Ca}^{2+}$ influx and results in inhibition of root elongation (Li et al., 2012). Cd can permeate guard cell PM $\mathrm{Ca}^{2+}$ channels (Perfus-Barbeoch et al., 2002) and may compete with $\mathrm{Ca}^{2+}$ for entry into rice root hairs through PM HACC, thus limiting $\mathrm{Ca}^{2+}$ influx (Li et al., 2012). Competitive effects appear likely given the ability of exogenous $\mathrm{Ca}^{2+}$ addition to alleviate $\mathrm{Cd}$ inhibition of root growth of both terrestrial and aquatic plants, implying competition for uptake (Zhang et al., 2012; RodriguezHernandez et al., 2015). Additionally, competitive inhibition by $\mathrm{Cd}$ of $\mathrm{Ca}^{2+}$ uptake through the wheat LCT1 transporter expressed in yeast has been observed (Clemens et al., 1998). Root hair growth in Arabidopsis is inhibited by Cd; it inhibits $\mathrm{Ca}^{2+}$ influx and so dissipates the apical $\left[\mathrm{Ca}^{2+}\right]_{\text {cyt }}$ gradient needed for growth (Fan et al., 2011). This could reflect block of root hair $\mathrm{Ca}^{2+}$ influx channels or Cd outcompeting $\mathrm{Ca}^{2+}$ for that influx pathway. However, Yeh et al. (2007) observed an increase in rice root $\left[\mathrm{Ca}^{2+}\right]_{\text {cyt }}$ following $15 \mathrm{~min}$ of $\mathrm{Cd}$ exposure, with a more tolerant variety sustaining a greater increase than a sensitive variety. In roots of the aquatic plant Typha latifolia, Cd exposure increases transcription of TPC1 which suggests that vacuoles might release $\mathrm{Ca}^{2+}$ to the cytosol (Rodriguez-Hernandez et al., 2015). Inhibitor treatments indicated involvement of NADPH oxidases, hydroxyl radicals and CIPK upstream of a MAP kinase induction that linked to tolerance (Yeh et al., 2007). Cd stimulates expression and activity of NADPH oxidases in cucumber roots but it is not known if these responses are $\mathrm{Ca}^{2+}$-dependent (Jakubowska et al., 2015). It is worth noting that it is not only an increase in $\left[\mathrm{Ca}^{2+}\right]_{\text {cyt }}$ that could stimulate NADPH oxidase activity but that also the restriction of $\mathrm{Ca}^{2+}$ entry to the cytosol could cause stimulation (Mortimer et al., 2008). It seems likely that in Arabidopsis roots it would be CAXs predominating in terminating a Cd-induced increase in $\left[\mathrm{Ca}^{2+}\right]_{\text {cyt }}$. CAX4 mediates $\mathrm{Cd}$ and $\mathrm{Ca}^{2+}$ transport into Arabidopsis thaliana vacuoles and is needed for correct growth under Cd stress (Mei et al., 2009). CAX1 expression is higher in roots of the Cd-tolerant A. halleri compared to the sensitive A. thaliana (Baliardini et al., 2015).

A key point for future studies is the intersect between $\mathrm{Cd}$ and hormones in relation to $\left[\mathrm{Ca}^{2+}\right]_{\text {cyt }}$. Exogenous $\mathrm{Ca}^{2+}$ can ameliorate Cd's inhibition of Arabidopsis root growth by counteracting effects of $\mathrm{NO}$ on auxin homeostasis ( $\mathrm{Hu}$ et al., 2013; Li P. et al., 2016; Yuan and Huang, 2016). Cd also interferes with auxin homeostasis in barley roots (Zelinova et al., 2015). Auxin itself can increase Arabidopsis root $\left[\mathrm{Ca}^{2+}\right]_{\text {cyt }}$ and this increase is mediated by CNGC14 at the PM, downstream of an unidentified auxin receptor (Shih et al., 2015). This begs the question of whether CNGC14 is an entry route for Cd and the pathway to disrupted auxin homeostasis. Additionally, Cd has been described as a "metallohormone" in that it triggers expression of brassinosteroid-regulated genes in Arabidopsis roots (Villiers et al., 2012). Brassinosteroids are themselves capable of transiently elevating $\left[\mathrm{Ca}^{2+}\right]_{\mathrm{cyt}}$ in Arabidopsis roots (through PM Ca ${ }^{2+}$ influx) and activate a possible DACC in wheat root PM (Straltsova et al., 2015). Again this raises the question of channel identity to help elucidate the relationship between $\mathrm{Cd}$ and brassinosteroid signaling and combat the effects of this potent soil contaminant.

\section{Copper, Gadolinium and Lead}

In contrast to $\mathrm{Cd}$, transition heavy metals could be capable of generating ROS directly and so perturb $\left[\mathrm{Ca}^{2+}\right]_{\text {cyt }}$ signaling. Transition metals can catalyze production of hydroxyl radicals from superoxide anion and hydrogen peroxide through the Haber-Weiss reaction, with $\mathrm{Cu}^{+}$and $\mathrm{Fe}^{2+}$ catalyzing hydroxyl radical production from hydrogen peroxide through the Fenton reaction (Richards et al., 2015). Unless levels of these catalytic metals are tightly controlled, production of hydroxyl radicals (the most potent of the ROS) could inflict significant oxidative damage. Taking $\mathrm{Cu}$ as the exemplar, it plays a positive role in hydroxyl radical-activated cell wall loosening for root elongation (Fry et al., 2002) and this could be coupled in Arabidopsis roots to hydroxyl radical-activation of PM Annexin1-mediated $\mathrm{Ca}^{2+}$ influx to stimulate exocytosis and growth (Foreman et al., 2003; Laohavisit et al., 2012). This model proposes regulation by extracellular hydroxyl radicals while Rodrigo-Moreno et al. (2013) have proposed that $\mathrm{Cu}^{+}$binding at the intracellular face of the PM in Arabidopsis root tips catalyzes hydroxyl radical production to regulate ion flux. This would allow coupling of $\mathrm{Cu}$ transport into the root to regulation of $\mathrm{PM} \mathrm{Ca}^{2+}$ influx channels. Certainly, low levels of $\mathrm{Cu}$ can promote elongation of Arabidopsis primary root and this effect is diminished by blocking PM Ca ${ }^{2+}$ influx channels (Demidchik et al., 2003). The effects of extracellular $\mathrm{Cu}$ on $\mathrm{PM} \mathrm{Ca}{ }^{2+}$ channels and therefore on $\left[\mathrm{Ca}^{2+}\right]_{\text {cyt }}$ signaling are likely to be complex. Electrophysiological analysis of Arabidopsis root epidermal PM has shown that $\mathrm{Cu}$ not only activates $\mathrm{Ca}^{2+}$ channels through ROS production (Annexin 1; Laohavisit et al., 2012) but also blocks channels, the molecular identity of which remains unknown (Demidchik et al., 2003).

Catalytic production of ROS by $\mathrm{Cu}$ is not the only route to modulating $\left[\mathrm{Ca}^{2+}\right]_{\text {cyt }}$. Longer-term exposure to $\mathrm{Cu}$ can stimulate exocytosis-mediated ROS production. Lin et al. (2013) found that inhibiting vesicle traffic with brefeldin also inhibited $\mathrm{Cu}$-stimulated ROS production in rice roots. Whether this involved NADPH oxidase or other ROS generators remains to be determined. Rice root $\left[\mathrm{Ca}^{2+}\right]_{\mathrm{cyt}}$ increases in response to $\mathrm{Cu}$ addition and could link to NADPH oxidases and CIPK activity leading to MAP kinase activation (Yeh et al., 2007). It triggers oxidative stress in Populus roots that leads to regulation of 
CaM genes, implicating perturbation of $\left[\mathrm{Ca}^{2+}\right]_{\mathrm{cyt}}$ (Guerra et al., 2009).

In common with $\mathrm{Cd}$, excess $\mathrm{Cu}$ also alters auxin homeostasis in roots and interferes with NO signaling (Lequeux et al., 2010; Kolbert et al., 2012). In excess, $\mathrm{Cu}$ stunts Arabidopsis root and root hair elongation and can inhibit lateral root outgrowth (Kolbert et al., 2012). Accumulation of lignin has been observed in both Arabidopsis and rice roots (Lequeux et al., 2010; Liu et al., 2015) and in the former accumulation is associated with the endodermis. It would now be interesting to ascertain whether such wall modification changes $\left[\mathrm{Ca}^{2+}\right]_{\text {cyt }}$ signals in central cells or affects $\left[\mathrm{Ca}^{2+}\right]_{\text {cyt }}$ propagative signaling to the shoot. Root tip cell death has also been observed (Huang et al., 2007; Lequeux et al., 2010; Rodrigo-Moreno et al., 2013). Cu-induced cell death in rice roots was attenuated by chelating extracellular $\mathrm{Ca}^{2+}$ thus implicating $\mathrm{Ca}^{2+}$ influx across the PM (Huang et al., 2007) while in Arabidopsis roots cell death was attenuated by addition of $\mathrm{Gd}^{3+}$ or verapamil as $\mathrm{PM} \mathrm{Ca}^{2+}$ channel blockers (RodrigoMoreno et al., 2013).

$\mathrm{Gd}^{3+}$ is routinely used as a $\mathrm{PM} \mathrm{Ca}{ }^{2+}$ channel blocker, for example with proven efficacy against Arabidopsis root epidermal and root hair HACC, DACC and VICC (Véry and Davies, 2000; Demidchik et al., 2002; Miedema et al., 2008). It is also effective against the root PM hydroxyl radical-activated and $\mathrm{H}_{2} \mathrm{O}_{2}$-activated $\mathrm{Ca}^{2+}$ influx channels (Demidchik et al., 2003, 2007) and the Annexin1-mediated pathway (Laohavisit et al., 2012). As a consequence $\mathrm{Gd}^{3+}$ lowers $\mathrm{Ca}^{2+}$ influx (measured with ${ }^{45} \mathrm{Ca}$; Demidchik et al., 2002). From this it can be anticipated that $\mathrm{Gd}^{3+}$ would have the capacity to dampen stressinduced $\left[\mathrm{Ca}^{2+}\right]_{\text {cyt }}$ signaling in roots, including that mediated by oxidative stress (Demidchik et al., 2003, 2007) and elicited by $\mathrm{NaCl}$ (Laohavisit et al., 2013). $\mathrm{Pb}$ is less well studied in terms of $\left[\mathrm{Ca}^{2+}\right]_{\text {cyt }}$. Exogenous $\mathrm{Ca}^{2+}$ can protect against root $\mathrm{Pb}$ accumulation, suggesting competitive uptake (RodriguezHernandez et al., 2015). However, $\mathrm{Pb}$ was found to evoke $\mathrm{Ca}^{2+}$ accumulation and diphenyleneiodinium-sensitive ROS increase in rice roots, the latter leading to MAPK activation (Huang and Huang, 2008). Entry of $\mathrm{Pb}$ into Arabidopsis roots involves $\mathrm{CNGC1}$ as its deletion confers greater tolerance but whether $\mathrm{Pb}$ permeates this channel is unknown (Sunkar et al., 2000). $\mathrm{Pb}$ has also been shown to increase expression of TPC1 in Typha roots (Rodriguez-Hernandez et al., 2015) but whether this results in increased $\left[\mathrm{Ca}^{2+}\right]_{c y t}$ in this or other roots is not known yet.

\section{MECHANICAL STRESS}

Roots experience a range of mechanical stimuli, induced as they encounter soil particles or neighboring roots. An increase in $\left[\mathrm{Ca}^{2+}\right]_{\text {cyt }}$ together with an apoplastic alkanisation are early effects induced by mechanical stimuli. One of the known downstream events from the increase in $\left[\mathrm{Ca}^{2+}\right]_{\text {cyt }}$ is the upregulation of touch-sensitive genes such as CML12 and CML24 (Braam, 1992). Mechanically triggered $\left[\mathrm{Ca}^{2+}\right]_{\mathrm{cyt}}$ changes are dependent on the type of stimulus and the responding tissue (Legue et al., 1997; Monshausen et al., 2009). For example, manually bending an Arabidopsis root induces a rapid, biphasic increase in $\left[\mathrm{Ca}^{2+}\right]_{\mathrm{cyt}}$ on the convex side of the roots where cells are stretched (Monshausen et al., 2009) while previously compressed cells on the concave side of the roots show a monophasic and less intense increase in $\left[\mathrm{Ca}^{2+}\right]_{\text {cyt }}$ upon return to their resting position. The source of $\mathrm{Ca}^{2+}$ is likely to be extracellular (Monshausen et al., 2009; Richter et al., 2009; Kurusu et al., 2012); with internal stores being mobilized to amplify the response (Chehab et al., 2009; Toyota and Gilroy, 2013).

Over-expressing MCA1 in Arabidopsis lead to an enhanced $\left[\mathrm{Ca}^{2+}\right]_{\text {cyt }}$ transient post mechanical stimulation by the addition of a membrane crenator, however, the mcal mutant showed no difference from the wild type (Nakagawa et al., 2007). Accordingly, Shih et al. (2014) showed no change in mcal apoplastic alkalinisation following root bending, which is closely related to the $\left[\mathrm{Ca}^{2+}\right]_{\text {cyt }}$ signature. Thus some levels of compensation occur in mutants deficient in mechanosensitive $\mathrm{Ca}^{2+}$ channels. In contrast to the MCAs, MSLs (Msc-iike) were identified in Arabidopsis due to their sequence similarity to the bacterial Mechanosensitive channels of small conductance (MscS) (Haswell et al., 2008). These are encoded by a multiple gene family of 10 members, with MSL9 and MSL10 found in the PM of root cells and required for a mechanosensitive channel activity. They are predominantly anion channels and their relationship to mechano-stimulated $\left[\mathrm{Ca}^{2+}\right]_{\mathrm{cyt}}$ increase has yet to be shown but may be through PM voltage regulation. At this point, it is unclear whether these channels represent mechano-sensors or act downstream of yet unknown mechanosensors.

Recently, the PM receptor-like kinase FERONIA has been implicated in regulating the Arabidopsis mechano-stimulated $\left[\mathrm{Ca}^{2+}\right]_{c y t}$ increase and downstream transcriptional regulation (Shih et al., 2014). feronia mutants lack the second peak of the biphasic increase in $\left[\mathrm{Ca}^{2+}\right]_{\text {cyt }}$ elicited in stretched cells by manual bending. However, the mechanism by which FERONIA can regulate $\left[\mathrm{Ca}^{2+}\right]_{\text {cyt }}$ remains unclear as its kinase activity is not essential and targets are unknown. As far as we know, this study was the first in which a mutant with an aberrant mechano-stimulated $\left[\mathrm{Ca}^{2+}\right]_{\text {cyt }}$ increase also showed a root skewing phenotype. Root skewing (deviation from the vertical when grown on vertical or inclined agar) may be influenced by mechano-sensing. At this point, it is unclear whether FERONIA also plays a role in the mechanical induction of lateral root formation (Richter et al., 2009).

\section{Cold Stress}

Cold plays a key role in the regulation of physiology and development; the signaling processes relaying non-stressful temperatures $\left(12^{\circ} \mathrm{C}\right.$ and above) have been reviewed by Wigge (2013). The signaling cascades activated by cold stress (typically $4^{\circ} \mathrm{C}$ experimentally) and their relations with hormonal signaling have been reviewed by Knight and Knight (2012), Jeon and Kim (2013), Shi et al. (2015) and Eremina et al. (2016). Most studies on the effect of cold stress on $\left[\mathrm{Ca}^{2+}\right]_{\text {cyt }}$ report on seedlings or leaves. From these it is well established that $\left[\mathrm{Ca}^{2+}\right]_{\mathrm{cyt}}$ elevation involves both $\mathrm{Ca}^{2+}$ influx across the PM and release from predominantly vacuolar stores (e.g., Knight et al., 1996; Mazars et al., 1997; Knight and Knight, 2000: Zhu et al., 2013). By 
using an extracellular $\mathrm{Ca}^{2+}$-reporting microelectrode, Sulaiman et al. (2012) confirmed that $\mathrm{Ca}^{2+}$ influx from the extracellular space is a component of the Arabidopsis root response to cold stress. For Arabidopsis roots, the $\left[\mathrm{Ca}^{2+}\right]_{\text {cyt }}$ response to cold stress measured using aequorin is lower in amplitude and of much shorter duration than leaves (Zhu et al., 2013). Using aequorin Plieth et al. (1999) determined that the faster the rate of cooling Arabidopsis roots, the greater the $\left[\mathrm{Ca}^{2+}\right]_{\text {cyt }}$ response. Sensitivity and magnitude of the $\left[\mathrm{Ca}^{2+}\right]_{\text {cyt }}$ cooling response were enhanced by low temperature but repeated exposure to cold lead to desensitizing of the response. These results imply the existence of $\mathrm{Ca}^{2+}$ transport systems that could be regulated at the post-translational and possibly transcriptional levels. In Arabidopsis, cold-induced $\left[\mathrm{Ca}^{2+}\right]_{\text {cyt }}$ elevation would activate a root $\mathrm{PM}$ calcium/calmodulin-regulated receptor-like kinase (CRLK1; Yang et al., 2010). This would then activate a specific mitogen-activated protein kinase kinase kinase (MEKK1) that then targets protein kinase kinase2 (MKK2; Furuya et al., 2013). This pathway leads to gene activation and freezing tolerance (Furuya et al., 2014). $\left[\mathrm{Ca}^{2+}\right]_{\text {cyt }}$ elevation would also activate CIPK3, that acts an intersect with ABA signaling (Kim et al., 2003). Part of the transcriptional response to cold in Arabidopsis could be activated by increased $\left[\mathrm{Ca}^{2+}\right]_{\text {cyt }}$ through CAMTA3 regulation of the transcriptional regulator CBF2 (C-Repeat/Dehydration Responsive Element Binding Factor2) (Doherty et al., 2009).

Cold stress has been found to depolarise the PM of root cells from cucumber and Triana bogotensis (Lyalin and Ktitorova, 1969; Minorsky and Spanswick, 1989), consistent with the effect of $\mathrm{Ca}^{2+}$ influx across the PM. A modeling exercise revealed the possible importance of a PM DACC in cold stress-induced $\left[\mathrm{Ca}^{2+}\right]_{\text {cyt }}$ elevation of roots (White, 2009). Cold has been shown to activate a PM DACC in leaf protoplasts (Carpaneto et al., 2007) but this has not yet been shown for roots. As microtubule destabilization activates the Arabidopsis root PM DACC (Thion et al., 1998), this could link to the increased cold-induced $\left[\mathrm{Ca}^{2+}\right]_{\text {cyt }}$ signal observed when microtubules are disrupted in Nicotiana plumbaginifolia leaf protoplasts (Mazars et al., 1997). Actin depolymerization is implicated in cold-induced $\mathrm{Ca}^{2+}$ influx across the PM into Medicago sativa suspension cells (Orvar et al., 2000). This in turn could relate to the coldinduced activation of pear pollen PM HACC that involves actin depolymerization (Wu et al., 2012). It would be timely therefore to investigate root PM for cold effects on HACC and DACC, exploring also the involvement of the cytoskeleton. In common with mechanical stress, cold stress could perturb the PM bilayer sufficiently to change $\mathrm{Ca}^{2+}$ channel activity. Work on $M$. sativa suspension cells showed that increasing membrane fluidity at $4^{\circ} \mathrm{C}$ prevented the $\mathrm{Ca}^{2+}$ influx across the PM that is necessary to trigger gene expression for freezing tolerance (Orvar et al., 2000). Conversely, imposing membrane rigidity at normal temperature triggers activation of the $\mathrm{Ca}^{2+}$-dependent MEKK1-MKK2MPK4 pathway in Arabidopsis seedlings (Furuya et al., 2014). The possibility that mechanosensitive channels are involved in cold-induced $\left[\mathrm{Ca}^{2+}\right]_{\text {cyt }}$ signaling merits investigation. However, recent work on rice roots indicates another route to $\mathrm{Ca}^{2+}$ influx. COLD1 has been identified as a PM activator of the heterotrimeric $\mathrm{G}$ protein subunit $\alpha$ (Ma Y. et al., 2015). It is required for cold-activated $\mathrm{Ca}^{2+}$ influx to roots (measured using extracellular $\mathrm{Ca}^{2+}$-reporting microelectrode) and elevation of root $\left[\mathrm{Ca}^{2+}\right]_{c y t}$ (aequorin and cameleon determinations). This indicates that heterotrimeric $G$ proteins lie upstream of PM $\mathrm{Ca}^{2+}$ channels in the cold response. In common with other stress responses, NADPH oxidase activity also appears in cold stress and needs to be placed in relation to $\mathrm{Ca}^{2+}$ channels. Arabidopsis roots exposed to cold stress use AtSRC2 (oybean gene Regulated by Cold2) to enhance $\mathrm{Ca}^{2+}$ activation of the AtRBOHF NADPH Oxidase (Kawarazaki et al., 2013). This suggests that $\mathrm{NADPH}$ oxidase activity can lie downstream of $\mathrm{Ca}^{2+}$ channel activity. Curtailing cold-induced $\left[\mathrm{Ca}^{2+}\right]_{\text {cyt }}$ elevation could involve vacuolar CAX1 activity in Arabidopsis (Catala et al., 2003).

\section{CONCLUSION AND FUTURE PROSPECTS}

A repeated message from this review is how incomplete our knowledge is of the channels mediating stress-induced $\left[\mathrm{Ca}^{2+}\right]_{\text {cyt }}$ increases, and by extension those of organelles. Many members of channel gene families still await characterization. The identification of new families of channels is challenging and will require different approaches linking forward and reverse genetics to electrophysiology. Targets of $\mathrm{Ca}^{2+}$-binding and interacting proteins also require further study. Components common to different abiotic stresses are emerging such as Arabidopsis CIPK23 in $\mathrm{K}^{+}$and nitrate deprivation. These common regulatory components are likely to represent critical steps where complex stress signals encountered in the soil are integrated in unified responses. Receptor like kinases such as FERONIA or PERK4 have emerged as new components in $\left[\mathrm{Ca}^{2+}\right]_{\text {cyt }}$ signaling and perhaps other related proteins will be found to have a role in abiotic stress signaling. Remodeling of calcium signaling machinery after stress is also apparent with the possibility of components common to different stresses. For example, Arabidopsis CNGC19 is upregulated under B limitation and salinity stress (Kugler et al., 2009). Finally, $\left[\mathrm{Ca}^{2+}\right]_{\text {cyt }}$-dependent transcriptional responses can be delineated and future work could include the impact of stress-induced calcium signaling on epigenetic inheritance (Sani et al., 2013; Probst and Scheid, 2015).

\section{AUTHOR CONTRIBUTIONS}

All authors listed, have made substantial, direct and intellectual contribution to the work, and approved it for publication. KW, $\mathrm{EM}, \mathrm{SS}$, and JD wrote the review. KW produced the figures.

\section{FUNDING}

Funding for this work was from the BBSRC (BB/K009869/1 and Doctoral Training Programme) and the University of Cambridge Broodbank Trust. 


\section{REFERENCES}

Armengaud, P., Beitling, R., and Amtmann, A. (2004). The potassium-dependent transcriptome of Arabidopsis reveals a prominent role of jasmonic acid in nutrient signaling. Plant Physiol. 136, 2556-2576. doi: 10.1104/pp.104.046482

Bai, L., Zhang, G., Zhou, Y., Zhang, Z., Wang, W., Du, Y., et al. (2009). Plasma membrane-associated proline-rich extension-like receptor kinase 4, a novel regulator of $\mathrm{Ca}^{2+}$ signaling, is required for abscisic acid responses in Arabidopsis thaliana. Plant J. 60, 314-327. doi: 10.1111/j.1365313X.2009.03956.x

Baliardini, C., Meyer, C.-L., Salis, P., Saumitou-Laprade, P., and Verbruggen, N. (2015). CATION EXCHANGER1 cosegregates with cadmium tolerance in the metal hyperaccumulator Arabidopsis halleri and plays a role in limiting oxidative stress in Arabidopsis Spp. Plant Physiol. 169, 549-559. doi: 10.1104/pp.15.01037

Barberon, M., Vermeer, J. E. M., De Bellis, D., Wang, P., Naseer, S., Anderson, T. G., et al. (2016). Adaptation of root function by nutrient-induced plasticity of endodermal differentiation. Cell 164, 447-459. doi: 10.1016/j.cell.2015.12.021

Batelli, G., Verslues, P. R., Agius, F., Qiu, Q., Fujii, H., Pan, S., et al. (2007). SOS2 promotes salt tolerance in part by interacting with the vacuolar $\mathrm{H}^{+}$. ATPase and upregulating its transport activity. Mol. Cell Biol. 27, 7781-7790. doi: 10.1128/MCB.00430-07

Behera, S., Wang, N., Zhang, C., Schmitz-Thom, I., Strohkamp, S., Schueltke, S., et al. (2015). Analyses of $\mathrm{Ca}^{2+}$ dynamics using a ubiquitin-10 promoterdriven Yellow Cameleon 3.6 indicator reveal reliable transgene expression and differences in cytoplasmic $\mathrm{Ca}^{2+}$ responses in Arabidopsis and rice (Oryza sativa) roots. New Phytol. 206, 751-760. doi: 10.1111/nph.13250

Bonza, M. C., Loro, G., Behera, S., Wong, A., Kudla, J., and Costa, A. (2013). Analyses of $\mathrm{Ca}^{2+}$ accumulation and dynamics in the endoplasmic reticulum of Arabidopsis root cells using a genetically encoded cameleon sensor. Plant Physiol. 163, 1230-1241. doi: 10.1104/pp.113.226050

Bonza, M. C., Luoni, L., Olivari, C., and DeMichelis, M. I. (2016). Plant type 2B Ca ${ }^{2+}$-ATPases: the diversity of isoforms of the model plant Arabidopsis thaliana. Adv. Biochem. Health Dis. 14, 227-241.

Boursiac, Y., and Harper, J. F. (2007). The origin and function of calmodulin regulated $\mathrm{Ca}^{2+}$ pumps in plants. J. Bioen. Biomem. 39, 409-414. doi: 10.1007/s10863-007-9104-z

Braam, J. (1992). Regulated expression of the calmodulin-related TCH genes in cultured Arabidopsis cells - induction by calcium and heat shock. Proc. Natl. Acad. Sci. U.S.A. 89, 3213-3216. doi: 10.1073/pnas.89.8.3213

Camacho-Cristobal, J. J., Martin-Rejano, E. M., Begona Herrera-Rodriguez, M., Teresa Navarro-Gochicoa, M., Rexach, J., and Gonzalez-Fontes, A. (2015). Boron deficiency inhibits root cell elongation via an ethylene/auxin/ROSdependent pathway in Arabidopsis seedlings. J. Expt. Bot. 66, 3831-3840. doi: 10.1093/jxb/erv186

Carpaneto, A., Ivashikina, N., Levchenko, V., Krol, E., Jeworutzki, E., Zhu, J.-K., et al. (2007). Cold transiently activates calcium-permeable channels in Arabidopsis mesophyll cells. Plant Physiol. 143, 487-494. doi: 10.1104/pp.106.090928

Carroll, A. D., Moyen, C., Van Kesteren, P., Tooke, F., Battey, N. H., and Brownlee, C. (1998). $\mathrm{Ca}^{2+}$, annexins, and GTP modulate exocytosis from maize root cap protoplasts. Plant Cell 10, 1267-1276. doi: 10.1105/tpc.10.8. 1267

Catala, R., Santos, E., Alonso, J. M., Ecker, J. R., Martinez-Zapater, J. M., and Salinas, J. (2003). Mutations in the $\mathrm{Ca}^{2+} / \mathrm{H}^{+}$transporter CAX1 increase CBF/DREB1 expression and the cold-acclimation response in Arabidopsis. Plant Cell 15, 2940-2951. doi: 10.1105/tpc.015248

Chehab, E. W., Eich, E., and Braam, J. (2009). Thigmomorphogenesis: a complex plant response to mechanostimulation. J. Expt. Bot. 60, 43-56. doi: 10.1093/jxb/ern315

Cheng, N. H., Pittman, J. K., Zhu, J. K., and Hirschi, K. D. (2004). The protein kinase SOS2 activates the Arabidopsis $\mathrm{H}^{+} / \mathrm{Ca}^{2+}$ antiporter CAX1 to integrate calcium transport and salt tolerance. J. Biol. Chem. 279, 2922-2926. doi: 10.1074/jbc.M309084200

Cheong, Y. H., Pandey, G. K., Grant, J. J., Batistic, O., Li, L., Kim, B.-G., et al. (2007). Two calcineurin B-like calcium sensors, interacting with protein kinase CIPK23, regulate leaf transcription and root potassium uptake in Arabidopsis. Plant J. 52, 223-239. doi: 10.1111/j.1365-313X.2007.03236.x
Chmielowska-Bak, J., Gryl, J., Rucinska-Sobkowiak, R., Arasimowicz-Jelonek, M., and Deckert, J. (2014). The new insights into cadmium sensing. Front. Plant Sci. 5:245. doi: 10.3389/fpls.2014.00245

Choi, W.-G., Toyota, M., Kim, S.-H., Hilleary, R., and Gilroy, S. (2014). Salt stress-induced $\mathrm{Ca}^{2+}$ waves are associated with rapid, long-distance root-toshoot signaling in plants. Proc. Natl. Acad. Sci. U.S.A. 111, 6497-6502. doi: 10.1073/pnas.1319955111

Christensen, A., Svensson, K., Persson, S., Jung, J., Michalak, M., Widell, S., et al. (2008). Functional characterization of Arabidopsis calreticulin1a: A key alleviator of endoplasmic reticulum. Plant Cell Physiol. 49, 912-924. doi: $10.1093 / \mathrm{pcp} / \mathrm{pcn} 065$

Chung, J. S., Zhu, J. K., Bressan, R. A., Hasagawa, P. M., and Shi, H. (2008). Reactive oxygen species mediate $\mathrm{Na}^{+}$-induced SOS1 mRNA stability in Arabidopsis. Plant J. 53, 554-565. doi: 10.1111/j.1365-313X.2007.03364.x

Clemens, S., Antosiewicz, D. M., Ward, J. M., Schachtman, D. B., and Schroeder, J. I. (1998). The plant cDNA LCT1 mediates the uptake of calcium and cadmium in yeast. Proc. Natl. Acad. Sci. U.S.A. 95, 12043-12048. doi: 10.1073/pnas.95.20.12043

Connorton, J. M., Webster, R. E., Cheng, N. H., and Pittman, J. K. (2012). Knockout of multiple Arabidopsis cation $/ \mathrm{H}^{+}$exchangers suggests isoform-specific roles in metal stress response, germination and see mineral nutrition. PLoS ONE 7:e47455. doi: 10.1371/journal.pone.0047455

Dark, A. M., Demidchik, V., Richards, S. L., Shabala, S. N., and Davies, J. M. (2011). Release of extracellular purines from plant roots and effect on ion fluxes. Plant Signal. Behav. 6, 1855-1857. doi: 10.4161/psb.6.11.17014

Davies, J. M. (2014). Annexin-mediated calcium signaling in plants. Plants 3, 128-140. doi: 10.3390/plants3010128

Demidchik, V., Bowen, H. C., Maathuis, F. J. M., Shabala, S. N., Tester, M. A., White, P. J., et al. (2002). Arabidopsis thaliana root non-selective cation channels mediate calcium uptake and are involved in growth. Plant J. 32, 799-808. doi: 10.1046/j.1365-313X.2002.01467.x

Demidchik, V., Cuin, T. A., Svistunenko, D., Smith, S. J., Miller, A. J., Shabala, S., et al. (2010). Arabidopsis root $\mathrm{K}^{+}$-efflux conductance activated by hydroxyl radicals: single-channel properties, genetic basis and involvement in stressinduced death. J. Cell Sci. 123, 1468-1479. doi: 10.1242/jcs.064352

Demidchik, V., Shabala, S. N., Coutts, K. B., Tester, M. A., and Davies, J. M. (2003). Free oxygen radicals regulate plasma membrane $\mathrm{Ca}^{2+}$ and $\mathrm{K}^{+}$-permeable channels in plant root cells. J. Cell Sci. 116, 81-88. doi: 10.1242/jcs.00201

Demidchik, V., Shabala, S. N., and Davies, J. M. (2007). Spatial variation in $\mathrm{H}_{2} \mathrm{O}_{2}$ response of Arabidopsis thaliana epidermal $\mathrm{Ca}^{2+}$ flux and plasma membrane $\mathrm{Ca}^{2+}$ channels. Plant J. 49, 377-386. doi: 10.1111/j.1365-313X.2006.02971.x

Demidchik, V., Shang, Z., Shin, R., Thompson, E. P., Rubio, L., Laohavisit, A., et al. (2009). Plant extracellular ATP signalling by plasma membrane NADPH oxidase and $\mathrm{Ca}^{2+}$ channels. Plant J. 58, 903-913. doi: 10.1111/j.1365313X.2009.03830.x

Deng, Y., Srivatava, R., and Howell, S. H. (2013). Protein kinase and ribonuclease domians of IRE1 confer stress tolerance, vegetative growth and reproductive development. Proc. Natl. Acad. Sci. U.S.A. 110, 19633-19638. doi: $10.1073 /$ pnas. 1314749110

DeWald, D. B., Torabinejad, J., Jones, C. A., Shope, J. C., Cangelosi, A. R., Thompson, J. E., et al. (2001). Rapid accumulation of phosphatidylinositol 4,5-bisphosphate and inositol 1,4,5-trisphosphate correlates with calcium mobilization in salt-stressed Arabidopsis. Plant Physiol. 126, 759-769. doi: 10.1104/pp.126.2.759

Dinneny, J. R., Long, T. A., Wang, J. Y., Jung, J. W., Mace, D., Pointer, S., et al. (2008). Cell identity mediates the response of Arabidopsis roots to abiotic stress. Science 320, 942-945. doi: 10.1126/science.1153795

Doherty, C. J., Van Buskirk, H. A., Myers, S. J., and Thomashow, M. F. (2009). Roles for Arabidopsis CAMTA transcription factors in cold-regulated gene expression and freezing tolerance. Plant Cell 21, 972-984. doi: 10.1105/tpc.108.063958

Donaldson, L., Ludidi, N., Knight, M. R., Gehring, C., and Denby, K. (2004). Salt and osmotic stress cause rapid increases in Arabidopsis thaliana cGMP levels. FEBS Letts. 569, 317-320. doi: 10.1016/j.febslet.2004.06.016

Drerup, M. M., Schluecking, K., Hashimoto, K., Manishankar, P., Steinhorst, L., Kuchitsu, K., et al. (2013). The Calcineurin B-Like calcium sensors CBL1 and CBL9 together with their interacting protein kinase CIPK26 regulate the Arabidopsis NADPH oxidase RBOHF. Mol. Plant 6, 559-569. doi: $10.1093 / \mathrm{mp} / \mathrm{sst} 009$ 
Dressler, L., Golbik, R., and Ulbrich-Hofmann, R. (2014). Lanthanides as substitutes for calcium ions in the activation of plant alpha-type phospholipase D. Biol. Chem. 395, 791-799. doi: 10.1515/hsz-2014-0112

Eremina, M., Rozhon, W., and Poppenberger, B. (2016). Hormonal control of cold stress responses in plants. Cell. Mol. Life Sci. 73, 797-810. doi: 10.1007/s00018015-2089-6

Fagerstedt, K. V. (2010). "Programmed cell death and aerenchyma formation under hypoxia," in Waterlogging Signalling and Tolerance in Plants, eds S. Mancuso and S. Shabala (Berlin: Springer), 99-118.

Fan, J.-L., Wei, X.-Z., Wan, L.-C., Zhang, L.-Y., Zhao, X.-Q., Liu, W.-Z., et al. (2011). Disarrangement of actin filaments and $\mathrm{Ca}^{2+}$ gradient by $\mathrm{CdCl}_{2}$ alters cell wall construction in Arabidopsis thaliana root hairs by inhibiting vesicular trafficking. J. Plant Physiol. 168, 1157-1167. doi: 10.1016/j.jplph.2011.01.031

Fischer, C., Kugler, A., Hoth, S., and Dietrich, P. (2013). An IQ domain mediates the interaction with calmodulin in a plant cyclic nucleotide-gated channel. Plant Cell Physiol. 54, 573-584. doi: 10.1093/pcp/pct021

Foreman, J., Demidchik, V., Bothwell, J. H. F., Mylona, P., Miedema, H., Torres, M. A., et al. (2003). Reactive oxygen species produced by NADPH oxidase regulate plant cell growth. Nature 422, 442-446. doi: 10.1038/nature01485

Fry, S. C., Miller, J. G., and Dumville, J. C. (2002). A proposed role for copper ions in cell wall loosening. Plant Soil 247, 57-67. doi: 10.1023/A:1021140022082

Furuya, T., Matsuoka, D., and Nanmori, T. (2013). Phosphorylation of Arabidopsis thaliana MEKK1 via $\mathrm{Ca}^{2+}$ signaling as a part of the cold stress response. J. Plant Res. 126, 833-840. doi: 10.1007/s10265-013-0576-0

Furuya, T., Matsuoka, D., and Nanmori, T. (2014). Membrane rigidification functions upstream of the MEKK1-MKK2-MPK4 cascade during cold acclimation in Arabidopsis thaliana. FEBS Lett. 588, 2025-2030. doi: 10.1016/j.febslet.2014.04.032

Gobert, A., Park, G., Amtmann, A., Sanders, D., and Maathuis, F. J. M. (2006). Arabidopsis thaliana cyclic nucleotide-gated channel 3 forms a non-selective ion transporter involved in germination and cation transport. J. Expt. Bot. 57, 791-800. doi: 10.1093/jxb/erj064

Goldbach, H. E., Yu, Q., Wingender, R., Schulz, M., Wimmer, M., Findeklee, P., et al. (2001). Rapid response reactions of roots to boron deprivation. J. Plant Nutr. Soil Sci. 164, 173-181. doi: 10.1002/1522-2624(200104)164:2<173::AIDJPLN173>3.3.CO;2-6

González-Fontes, A., Herrera-Rodriguez, M. B., Martin-Rejano, E. M., NavarroGochicoa, M. T., Rexach, J., and Camacho-Cristobal, J. J. (2016). Root responses to boron deficiency mediated by ethylene. Front. Plant Sci. 6:1103. doi: 10.3389/fpls.2015.01103

Gonzali, S., Loreti, E., Cardarelli, F., Novi, G., Parlanti, S., Pucciariello, C., et al. (2015). Universal stress protein HRU1 mediates ROS homeostasis under anoxia. Nat. Plants 1, 15151. doi: 10.1038/NPLANTS.2015.151

Guerra, F., Duplessis, S., Kohler, A., Martin, F., Tapia, J., Lebed, P., et al. (2009). Gene expression analysis of Populus deltoides roots subjected to copper stress. Environ. Exp. Bot. 67, 335-344. doi: 10.1016/j.envexpbot.2009.08.004

Guo, J., Zeng, W., Chen, Q., Lee, C., Chen, L., Yang, Y., et al. (2016). Structure of the voltage-gated two-pore channel TPC1 from Arabidopsis thaliana. Nature 531, 196-201. doi: 10.1038/nature16446

Guo, K.-M., Babourina, O., Christopher, D. A., Borsics, T., and Rengel, Z. (2008). The cyclic nucleotide-gated channel, AtCNGC10, influences salt tolerance in Arabidopsis. Physiol. Plant. 134, 499-507. doi: 10.1111/j.13993054.2008.01157.x

Haswell, E. S., Peyronnet, R., Barbier-Brygoo, H., Meyerowitz, E. M., and Frachisse, J. M. (2008). Two MscS homologs provide mechanosensitive channel activities in the Arabidopsis root. Curr. Biol. 18, 730-734. doi: 10.1016/j.cub.2008. 04.039

Ho, C.-H., Lin, S.-H., Hu, H.-C., and Tsay, Y.-F. (2009). CHL1 functions as a nitrate sensor in plants. Cell 138, 1184-1194. doi: 10.1016/j.cell.2009.07.004

Hossain, M. A., Henriquez-Valencia, C., Gómez-Páez, M., Medina, J., Orellana, A., Vicente-Carbajosa, J., et al. (2016). Identification of novel components of the unfolded protein response in Arabidopsis. Front. Plant Sci. 7:650. doi: 10.3389/fpls.2016.00650

Hou, C. C., Tian, W., Kleist, T., He, K., Garcia, V., Bai, F., et al. (2014). DUF221 proteins are a family of osmosensitive calcium-permeable cation channels conserved across eukaryotes. Cell Res. 24, 632-635. doi: 10.1038/cr.2014.14

Hou, Q., Ufer, G., and Bartels, D. (2016). Lipid signalling in plant responses to abiotic stress. Plant Cell Environ. 39, 1029-1048. doi: 10.1111/pce.12666
Hu, H. C., Wang, Y. Y., and Tsay, Y. F. (2009). AtCIPK8, a CBL-interacting protein kinase, regulates the low-affinity phase of the primary nitrate response. Plant J. 57, 264-278. doi: 10.1111/j.1365-313X.2008.03685.X

Hu, Y. F., Zhou, G., Na, X. F., Yang, L., Nan, W. B., Liu, X., et al. (2013). Cadmium interferes with maintenance of auxin homeostasis in Arabidopsis seedlings. J. Plant Physiol. 170, 965-975. doi: 10.1016/j.jplph.2013.02.008

Hua, B. G., Mercier, R. W., and Zielinski, R. E. (2003). Functional interaction of calmodulin with a plant cyclic nucleotide gated cation channel. Plant Physiol. Biochem. 41, 945-954. doi: 10.1016/j.plaphy.2003.07.006

Huang, T.-L., and Huang, H.-J. (2008). ROS and CDPK-like kinase-mediated activation of MAP kinase in rice roots exposed to lead. Chemosphere 71, 1377-1385. doi: 10.1016/j.chemosphere.2007.11.031

Huang, W.-C., Huang, D.-D., Chien, P.-S., Yeh, C.-M., Chen, P.-Y., Chi, W.-C., et al. (2007). Protein tyrosine dephosphorylation during copper-induced cell death in rice roots. Chemosphere 69, 55-62. doi: 10.1016/j.chemosphere.2007.04.073

Hunt, L., Otterhag, L., Lee, J. C., Lasheen, T., Hunt, J., Seki, M., et al. (2004). Gene-specific expression and calcium activation of Arabidopsis thaliana phospholipase C isoforms. New Phytol. 162, 643-654. doi: 10.1111/j.14698137.2004.01069.x

Isner, J. C., Nühse, T., and Maathuis, F. J. M. (2012). The cyclic nucleotide cGMP is involved in plant hormone signalling and alters phosphorylation of Arabidopsis thaliana root proteins. J. Expt. Bot. 63, 3199-3205. doi: 10.1093/jxb/ ers045

Jakubowska, D., Janicka-Russak, M., Kabala, K., Migocka, M., and Reda, M. (2015). Modification of plasma membrane NADPH oxidase activity in cucumber seedling roots in response to cadmium stress. Plant Sci. 234, 50-59. doi: 10.1016/j.plantsci.2015.02.005

Jeon, J., and Kim, J. (2013). Cold stress signaling networks in Arabidopsis. J. Plant Biol. 56, 69-76. doi: 10.1007/s12374-013-0903-y

Jiang, H. B., Wang, S. F., Yang, F., Zhang, Z. H., Qiu, H. C., Yi, Y., et al. (2015). Plant growth, nitrate content and Ca signaling in wheat (Triticum aestivum L.) roots under different nitrate supply. Plant Sci. J. 33, 362-368.

Jiao, Y., Sun, L., Song, Y., Wang, L., Liu, L., Zhang, L., et al. (2013). AtrbohD and AtrbohF positively regulate abscisic acid-inhibited primary root growth by affecting $\mathrm{Ca}^{2+}$ signalling and auxin response of roots in Arabidopsis. J. Expt. Bot. 64, 4183-4192. doi: 10.1093/jxb/ert228

Jin, Y. K., Jing, W., Zhang, Q., and Zhang, W. H. (2015). Cyclic nucleotide gated channel 10 negatively regulates salt tolerance by mediating $\mathrm{Na}^{+}$ transport in Arabidopsis. J. Plant Res. 128, 211-220. doi: 10.1007/s10265-0140679-2

Kamano, S., Kume, S., Iida, K., Lei, K.-J., Nakano, M., Nakayama, Y., et al. (2015). Transmembrane topologies of $\mathrm{Ca}^{2+}$-permeable mechanosensitive channels MCA1 and MCA2 in Arabidopsis thaliana. J. Biol. Chem. 290, 30901-30909. doi: 10.1074/jbc.M115.692574

Kanehara, K., Yu, C.-Y., Cho, Y., Cheong, W.-F., Torta, F., Shui, G., et al. (2015). Arabidopsis AtPLC2 is a primary phosphoinositide-specific phospholipase $\mathrm{C}$ in phopshoinositide metabolism and the endoplasmic reticulum stress response. PLOS Genet. 11:e1005511. doi: 10.1371/journal.pgen. 1005511

Kasajima, I., Ide, Y., Hirai, M. Y., and Fujiwara, T. (2010). WRKY6 is involved in the response to boron deficiency in Arabidopsis thaliana. Physiol. Plant. 139, 80-92. doi: 10.1111/j.1399-3054.2010.01349.x

Kawarazaki, T., Kimura, S., Iizuka, A., Hanamata, S., Nibori, H., Michikawa, M., et al. (2013). A low temperature-inducible protein AtSRC2 enhances the ROSproducing activity of NADPH oxidase AtRbohF. Biochim. Biophys. Acta Mol. Cell Res. 1833, 2775-2780. doi: 10.1016/j.bbamcr.2013.06.024

Kiegle, E., Moore, C. A., Haseloff, J., Tester, M. A., and Knight, M. R. (2000). Celltype-specific calcium responses to drought, salt and cold in the Arabidopsis root. Plant J. 23, 267-278. doi: 10.1046/j.1365-313x.2000.00786.x

Kim, K. N., Cheong, Y. H., Grant, J. J., Pandey, G. K., and Luan, S. (2003). CIPK3, a calcium sensor-associated protein kinase that regulates abscisic acid and cold signal transduction in Arabidopsis. Plant Cell 15, 411-423. doi: $10.1105 /$ tpc.006858

Kim, Y., Wang, M., Bai, Y., Zeng, Z., Guo, F., Han, N., et al. (2014). Bcl-2 suppresses activation of VPEs by inhibiting cytosolic $\mathrm{Ca}^{2+}$ level with elevated $\mathrm{K}^{+}$efflux in NaCl-induced PCD in rice. Plant Physiol. Biochem. 80, 168-175. doi: 10.1016/j.plaphy.2014.04.002 
Kintzer, A. F., and Stroud, R. M. (2016). Structure, inhibition and regulation of two-pore channel TPC1 from Arabidopsis thaliana. Nature 531, 258-264. doi: 10.1038 /nature 17194

Knight, H., and Knight, M. R. (2000). Imaging spatial and cellular characteristics of low temperature calcium signature after cold acclimation in Arabidopsis. J. Expt. Bot. 51, 1679-1686. doi: 10.1093/jexbot/51.351.1679

Knight, H., Trewavas, A. J., and Knight, M. R. (1996). Cold calcium signaling in Arabidopsis involves two cellular pools and a change in calcium signature after acclimation. Plant Cell 8, 489-503. doi: 10.1105/tpc.8.3.489

Knight, H., Trewavas, A. J., and Knight, M. R. (1997). Calcium signalling in Arabidopsis thaliana responding to drought and salinity. Plant J. 12, 1067-1078. doi: 10.1046/j.1365-313X.1997.12051067.x

Knight, M. R., and Knight, H. (2012). Low-temperature perception leading to gene expression and cold tolerance in higher plants. New Phytol. 195, 737-751. doi: 10.1111/j.1469-8137.2012.04239.x

Kobayashi, B., Matoh, T., and Azuma, J. (1996). Two chains of rhamnogalacturonan II are cross-linked by borate-diol ester bonds in higher plant cell walls. Plant Physiol. 110, 1017-1020.

Kolbert, Z., Petö, A., Lehotai, N., Feigl, G., and Erdei, L. (2012). Long-term copper $\left(\mathrm{Cu}^{2+}\right)$ exposure impacts on auxin, nitric oxide $(\mathrm{NO})$ metabolism and morphology of Arabidopsis thaliana L. Plant Growth Regul. 68, 151-159. doi: 10.1007/s10725-012-9701-7

Koshiba, T., Ishihara, A., and Matoh, T. (2010). Boron nutrition of cultured Tobacco BY-2 Cells. VI. Calcium is involved in early responses to boron deprivation. Plant Cell Physiol. 51, 323-327. doi: 10.1093/pcp/pcp179

Kugler, A., Koehler, B., Palme, K., Wolff, P., and Dietrich, P. (2009). Salt-dependent regulation of a CNG channel subfamily in Arabidopsis. BMC Plant Biol. 9:140. doi: 10.1186/1471-2229-9-140

Kurusu, T., Nishikawa, D., Yamazaki, Y., Gotoh, M., Nakano, M., Hamada, H., et al. (2012). Plasma membrane protein OsMCA1 is involved in regulation of hypo-osmotic shock-induced $\mathrm{Ca}^{2+}$ influx and modulates generation of reactive oxygen species in cultured rice cells. BMC Plant Biol. 12:11. doi: 10.1186/14712229-12-11

Laohavisit, A., and Davies, J. M. (2011). Annexins. New Phytol. 189, 40-53. doi: 10.1111/j.1469-8137.2010.03533.x

Laohavisit, A., Richards, S. L., Shabala, L., Chen, C., Colaço, R., Swarbreck, S. M., et al. (2013). Salinity-induced calcium signaling and root adaptation in Arabidopsis require the regulatory protein annexin1. Plant Physiol. 163, 253-262. doi: 10.1104/pp.113.217810

Laohavisit, A., Shang, Z.-L., Rubio, L., Cuin, T. A., Véry, A. A., Wang, A. H., et al. (2012). Arabidopsis annexin 1 mediates the radical-activated plasma membrane $\mathrm{Ca}^{2+}$ and $\mathrm{K}^{+}$-permeable conductance in root cells. Plant Cell 24, 1522-1533. doi: 10.1105/tpc.112.097881

Latz, A., Mehlmer, N., Zapf, S., Mueller, T. D., Wurzinger, B., Pfister, B., et al. (2013). Salt stress triggers phosphorylation of the Arabidopsis vacuolar $\mathrm{K}^{+}$ channel TPK1 by calcium-dependent protein kinases (CDPKs). Mol. Plant 6, 1274-1289. doi: 10.1093/mp/sss158

Legue, V., Blancaflor, E., Wymer, C., Perbal, G., Fahtin, D., and Gilroy, S. (1997). Cytoplasmic free calcium in Arabidopsis roots changes in response to touch but not gravity. Plant Physiol. 114, 789-800. doi: 10.1104/pp.114.3.789

Lequeux, H., Hermans, C., Lutts, S., and Verbruggen, N. (2010). Response to copper excess in Arabidopsis thaliana: impact on the root system architecture, hormone distribution, lignin accumulation and mineral profile. Plant Physiol. Biochem. 48, 673-682. doi: 10.1016/j.plaphy.2010.05.005

Léran, S., Edel, K. H., Pervent, M., Hashimoto, K., Corratge-Faillie, C., Offenborn, J. N., et al. (2015). Nitrate sensing and uptake in Arabidopsis are enhanced by ABI2, a phosphatase inactivated by the stress hormone abscisic acid. Sci. Signal. 8, ra43. doi: 10.1126/scisignal.aaa4829

Li, G., Boudsocq, M., Hem, S., Vialaret, J., Rossignol, M., Maurel, C., et al. (2015). The calcium-dependent protein kinase CPK7 acts on root hydraulic conductivity. Plant Cell Environ. 38, 1312-1320. doi: 10.1111/pce.12478

Li, J., Long, Y., Qi, G. N., Xu, Z. J., Wu, W. H., and Wang, Y. (2014). The OsAKT1 channel is critical for $\mathrm{K}^{+}$uptake in rice roots and is modulated by the rice CBL1-CIPK23 complex. Plant Cell 26, 3387-3402. doi: 10.1105/tpc.114. 123455

Li, L., Kim, B.-G., Cheong, Y. H., Pandey, G. K., and Luan, S. (2006). A Ca ${ }^{2+}$ signalling pathway regulates a $\mathrm{K}^{+}$channel for low $\mathrm{K}^{+}$response in Arabidopsis. Proc. Natl. Acad. Sci. U.S.A. 103, 12625-12630. doi: 10.1073/pnas.0605129103
Li, P., Zhao, C. Z., Zhang, Y. Q., Wang, X. M., Wang, X. Y., Wang, J. F., et al. (2016). Calcium alleviates cadmium-induced inhibition on root growth by maintaining auxin homeostasis in Arabidopsis seedlings. Protoplasma 253, 185-200. doi: 10.1007/s00709-015-0810-9

Li, P. H., Zhang, G. Y., Gonzales, N., Guo, Y. Q., Hu, H. H., Park, S. H., et al. (2016). $\mathrm{Ca}^{2+}$-regulated and diurnal rhythm-regulated $\mathrm{Na}^{+} / \mathrm{Ca}^{2+}$ exchanger AtNCL affects flowering time and auxin signalling in Arabidopsis. Plant Cell Environ. 39, 377-392. doi: 10.1111/pce.12620

Li, S., Yu, J., Zhu, M., Zhao, F., and Luan, S. (2012). Cadmium impairs ion homeostasis by altering $\mathrm{K}^{+}$and $\mathrm{Ca}^{2+}$ channel activities in rice root hairs. Plant Cell Environ. 35, 1998-2013. doi: 10.1111/j.1365-3040.2012.02532.x

Lin, C. Y., Trinh, N. N., Fu, S. F., Hsiung, Y. C., Chia, L. C., Lin, C. W., et al. (2013). Comparison of early transcriptome responses to copper and cadmium in rice roots. Plant Mol. Biol. 81, 507-522. doi: 10.1007/s11103-013-0020-9

Liu, J. P., Ishitani, M., Halfter, U., Kim, C. S., and Zhu, J. K. (2000). The Arabidopsis thaliana SOS2 gene encodes a protein kinase that is required for salt tolerance. Proc. Natl. Acad. Sci. U.S.A. 97, 3730-3734. doi: 10.1073/pnas.97. 7.3730

Liu, J.-X., Srivastava, R., Che, P., and Howell, S. H. (2007). Salt stress responses in Arabidopsis utilize a signal transduction pathway related to endoplasmic reticulum stress signaling. Plant J. 51, 897-909. doi: 10.1111/j.1365313X.2007.03195.x

Liu, L., Li, Q., Yin, B., Zhang, H., Lin, B., Wu, Y., et al. (2011). The endoplasmic reticulum-associated degradation is necessary for plant salt tolerance. Cell Res. 21, 957-969. doi: 10.1038/cr.2010.181

Liu, Q., Zheng, L., He, F., Zhao, F.-J., Shen, Z., and Zheng, L. (2015). Transcriptional and physiological analyses identify a regulatory role for hydrogen peroxide in the lignin biosynthesis of copper-stressed rice roots. Plant Soil 387, 323-336. doi: 10.1007/s11104-014-2290-7

Lokdarshi, A., Conner, W. C., McClintock, C., Li, T., and Roberts, D. M. (2016). Arabidopsis CML38, a calcium sensor that localizes to ribonucleoprotein complexes under hypoxia stress. Plant Physiol. 170, 1046-1059. doi: 10.1104/pp.15.01407

Lu, G., Wang, X., Liu, J., Yu, K., Gao, Y., Liu, H., et al. (2014). Application of T-DNA activation tagging to identify glutamate receptor-like genes that enhance drought tolerance in plants. Plant Cell Rep. 33, 617-631. doi: 10.1007/s00299014-1586-7

Lyalin, O. O., and Ktitorova, I. N. (1969). Resting potential of the root hair of Trianea bogotensis. Sov. Plant Phys. 16, 214-221.

Ma, L., Zhang, H., Sun, L., Jiao, Y., Zhang, G., Miao, C., et al. (2012). NADPH oxidase AtrbohD and AtrbohF function in ROS-dependent regulation of $\mathrm{Na}^{+} / \mathrm{K}^{+}$homeostasis in Arabidopsis under salt stress. J. Expt. Bot. 63, 305-317. doi: $10.1093 / \mathrm{jxb} / \mathrm{err} 280$

Ma, Q., Tang, R. J., Zheng, X. J., Wang, S. M., and Luan, S. (2015). The calcium sensor CBL7 modulates plant responses to low nitrate in Arabidopsis. Biochem. Biophys. Res. Commun. 468, 59-65. doi: 10.1016/j.bbrc.2015.10.164

Ma, Y., Dai, X. Y., Xu, Y. Y., Luo, W., Zheng, X. M., Zeng, D. L., et al. (2015). COLD1 confers chilling tolerance in rice. Cell 160, 1209-1221. doi: 10.1016/j.cell.2015.01.046

Maathuis, F. J. M. (2014). Sodium in plants: perception, signalling and regulation of sodium fluxes. J. Expt. Bot. 65, 849-858. doi: 10.1093/jxb/ert326

Mazars, C., Thion, L., Thuleau, P., Graziana, A., Knight, M. R., Moreau, M., et al. (1997). Organization of cytoskeleton controls the changes in cytosolic calcium of cold-shocked Nicotiana plumbaginifolia protoplasts. Cell Calcium 22, 413-420. doi: 10.1016/S0143-4160(97)90025-7

McAinsh, M. R., and Pittman, J. K. (2009). Shaping the calcium signature. New Phytol. 181, 275-294. doi: 10.1111/j.1469-8137.2008.02682.x

McLoughlin, F., Galvan-Ampudia, C. S., Julkowska, M. M., Caarls, L., van der Does, D., Lauriere, C., et al. (2012). The Snfl-related protein kinases SnRK2.4 and SnRK2.10 are involved in maintenance of root system architecture during salt stress. Plant J. 72, 436-449. doi: 10.1111/j.1365-313X.2012. 05089.x

Mehlmer, N., Wurzinger, B., Stael, S., Hofmann-Rodrigues, D., Csaszar, E., Pfister, B., et al. (2010). The $\mathrm{Ca}^{2+}$-dependent protein kinase CPK3 is required for MAPK-independent salt-stress acclimation in Arabidopsis. Plant J. 63, 484-498. doi: 10.1111/j.1365-313X.2010.04257.x

Mei, H., Cheng, N. H., Zhao, J., Park, S., Escareno, R. A., Pittman, J. K., et al. (2009). Root development under metal stress in Arabidopsis thaliana requires 
the $\mathrm{H}^{+}$/cation antiporter CAX4. New Phytol. 183, 95-105. doi: 10.1111/j.14698137.2009.02831.x

Meringer, M. V., Villasuso, A. L., Peppino, M. M., Usorach, J., Pasquare, S. J., Giusto, N. M., et al. (2016). Saline and osmotic stresses stimulate PLD/diacylglycerol kinase activities and increase the level of phosphatidic acid and proline in barley roots. Environ. Expt. Bot. 128, 69-78. doi: 10.1016/j.envexpbot.2016.03.011

Miedema, H., Demidchik, V., Véry, A.-A., Bothwell, J. H. F., Brownlee, C., and Davies, J. M. (2008). Two voltage-dependent calcium channels co-exist in the apical plasma membrane of Arabidopsis thaliana root hairs. New Phytol. 179, 378-385. doi: 10.1111/j.1469-8137.2008.02465.x

Miller, G., Schlauch, K., Tam, R., Cortes, D., Torres, M. A., Shulaev, V., et al. (2009). The plant NADPH oxidase RBOHD mediates rapid systemic signaling in response to diverse stimuli. Sci. Signal. 2, ra45. doi: 10.1126/scisignal. 2000448

Minorsky, P. V., and Spanswick, R. M. (1989). Electrophysiological evidence for a role for calcium in temperature sensing by roots of cucumber seedlings. Plant Cell Env. 12, 137-143. doi: 10.1111/j.1365-3040.1989.tb01925.x

Monshausen, G. B., Bibikova, T. N., Weisenseel, M. H., and Gilroy, S. (2009). Ca ${ }^{2+}$ regulates reactive oxygen species production and $\mathrm{pH}$ during mechanosensing in Arabidopsis roots. Plant Cell 21, 2341-2356. doi: 10.1105/tpc. 109.068395

Moore, C. A., Bowen, H. C., Scrase-Field, S., Knight, M. R., and White, P. J. (2002). The deposition of suberin lamellae determines the magnitude of cytosolic $\mathrm{Ca}^{2+}$ elevations in root endodermal cells subjected to cooling. Plant J. 30, 457-465. doi: 10.1046/j.1365-313X.2002.01306.x

Mortimer, J. C., Laohavisit, A., Miedema, H., and Davies, J. M. (2008). Voltage, reactive oxygen species and the influx of calcium. Plant Sig. Behav. 3, 698-699. doi: $10.4161 /$ psb.3.9.6405

Mühling, K. H., Wimmer, M., and Goldbach, H. E. (1998). Apoplastic and membrane associated $\mathrm{Ca}^{2+}$ in leaves and roots as affected by boron deficiency. Physiol. Plant. 102, 179-184. doi: 10.1034/j.1399-3054.1998.1020204.x

Nakagawa, Y., Katagiri, T., Shinozaki, K., Qi, Z., Tatsumi, H., Furuichi, T., et al. (2007). Arabidopsis plasma membrane protein crucial for $\mathrm{Ca}^{2+}$ influx and touch sensing in roots. Proc. Natl. Acad. Sci. U.S.A. 104, 3639-3644. doi: 10.1073/pnas.0607703104

Nieves-Cordones, M., Miller, A. J., Aleman, F., Martinez, V., and Rubio, F. (2008). A putative role for the plasma membrane potential in the control of the expression of the gene encoding the tomato high-affinity potassium transporter HAK5. Plant Mol. Biol. 68, 521-532. doi: 10.1007/s11103-008-9388-3

Oiwa, Y., Kitayama, K., and Matoh, T. (2013). Boron deprivation immediately causes cell death in growing roots of Arabidopsis thaliana (L.) Heynh. Soil Sci. Plant Nutr. 59, 621-627. doi: 10.1080/00380768.2013.813382

Ordenes, V. R., Moreno, I., Maturana, D., Norambuena, L., Trewavas, A. J., and Orellana, A. (2012). In vivo analysis of the calcium signature in the plant Golgi apparatus reveals unique dynamics. Cell Calcium 52, 397-404. doi: 10.1016/j.ceca.2012.06.008

Orvar, B. L., Sangwan, V., Omann, F., and Dhindsa, R. S. (2000). Early steps in cold sensing by plant cells: the role of actin cytoskeleton and membrane fluidity. Plant J. 23, 785-794. doi: 10.1046/j.1365-313x.2000.00845.x

Pandey, N., Ranjan, A., Pant, P., Tripathi, R. K., Ateek, F., Pandey, H. P., et al. (2013). CAMTA 1 regulates drought responses in Arabidopsis thaliana. BMC Genomics 14:216. doi: 10.1186/1471-2164-14-216

Peiter, E., Maathuis, F. J. M., Mills, L. N., Knight, H., Pelloux, J., Hetherington, A. M., et al. (2005). The vacuolar $\mathrm{Ca}^{2+}$-activated channel TPC1 regulates germination and stomatal movement. Nature 434, 404-408. doi: 10.1038/nature03381

Perfus-Barbeoch, L., Leonhardt, N., Vavasseur, A., and Forestier, C. (2002). Heavy metal toxicity: cadmium permeates through calcium channels and disturbs the plant water status. Plant J. 32, 539-548. doi: 10.1046/j.1365-313X.2002. 01442.x

Petrov, V., Hille, J., Mueller-Roeber, B., and Gechev, T. S. (2015). ROS-mediated abiotic stress-induced programmed cell death in plants. Front. Plant Sci. 6:69. doi: $10.3389 /$ fpls.2015.00069

Plieth, C., Hansen, U. P., Knight, H., and Knight, M. R. (1999). Temperature sensing by plants: the primary characteristics of signal perception and calcium response. Plant J. 18, 491-497. doi: 10.1046/j.1365-313X.1999.00471.x

Pottosin, I., Maria Velarde-Buendia, A., Bose, J., Fuglsang, A. T., and Shabala, S. (2014). Polyamines cause plasma membrane depolarization, activate $\mathrm{Ca}^{2+}$-, and modulate $\mathrm{H}^{+}$-ATPase pump activity in pea roots. J. Expt. Bot. 65, 2463-2472. doi: $10.1093 / \mathrm{jxb} /$ eru133

Probst, A. V., and Scheid, O. M. (2015). Stress-induced structural changes in plant chromatin. Curr. Opin. Plant Biol. 27, 8-16. doi: 10.1016/j.pbi.2015.05.011

Qin, W. S., Pappan, K., and Wang, X. M. (1997). Molecular heterogeneity of phospholipase D (PLD) - Cloning of PLD gamma and regulation of plant PLD gamma, -beta, and -alpha by polyphosphoinositides and calcium. J. Biol. Chem. 272, 28267-28273. doi: 10.1074/jbc.272.45.28267

Qiu, Q. S., Guo, Y., Quintero, F. J., Pardo, J. M., Schumaker, K. S., and Zhu, J. K. (2004). Regulation of vacuolar $\mathrm{Na}^{+} / \mathrm{H}^{+}$exchange in Arabidopsis thaliana by the salt-overly-sensitive (SOS) pathway. J. Biol. Chem. 279, 207-215. doi: 10.1074/jbc.M307982200

Quiles-Pando, C., Rexach, J., Navarro-Gochicoa, M. T., Camacho-Cristóbal, J. J., Herrera-Rodríguez, M. B., and González-Fontes, A. (2013). Boron deficiency increases the level of cytosolic $\mathrm{Ca}^{2+}$ and expression of $\mathrm{Ca}^{2+}$-related genes in Arabidopsis thaliana roots. Plant Physiol. Biochem. 65, 55-60. doi: 10.1016/j.plaphy.2013.01.004

Quintero, F. J., Martinez-Atienza, J., Villalta, I., Jiang, X., Kim, W. Y., Ali, Z., et al. (2011). Activation of the plasma membrane $\mathrm{Na} / \mathrm{H}$ antiporter Salt-Overly-Sensitive 1 (SOS1) by phosphorylation of an auto-inhibitory C-terminal domain. Proc. Natl. Acad. Sci. U.S.A. 108, 2611-2616. doi: 10.1073/pnas.1018921108

Ragel, P., Rodenas, R., Garcia-Martin, E., Andres, Z., Villalta, I., NievesCordones, M., et al. (2015). SOS the CBL-interacting protein kinase CIPK23 regulates HAK5-mediated high-affinity $\mathrm{K}^{+}$uptake in Arabidopsis roots. Plant Physiol. 169, 2863-2873. doi: 10.1104/pp.15.01401

Richards, S. L., Wilkins, K. A., Swarbreck, S. M., Anderson, A., Habib, N., McAinsh, M., et al. (2015). The hydroxyl radical; from seed to seed. J. Expt. Bot. 66, 37-46. doi: 10.1093/jxb/eru398

Richter, G. L., Monshausen, G. B., Krol, A., and Gilroy, S. (2009). Mechanical stimuli modulate lateral root organogenesis. Plant Physiol. 151, 1855-1866. doi: 10.1104/pp.109.142448

Riveras, E., Alvarez, J. M., Vidal, E. A., Oses, C., Vega, A., and Gutierrez, R. A. (2015). The calcium ion is a second messenger in the nitrate signaling pathway of Arabidopsis. Plant Physiol. 169, 1397-1404. doi: 10.1104/pp.15. 00961

Rodrigo-Moreno, A., Andres-Colas, N., Poschenrieder, C., Gunse, B., Penarrubia, L., and Shabala, S. (2013). Calcium- and potassium-permeable plasma membrane transporters are activated by copper in Arabidopsis root tips: linking copper transport with cytosolic hydroxyl radical production. Plant Cell Environ. 36, 844-855. doi: 10.1111/pce.12020

Rodriguez-Hernandez, M. C., Bonifas, I., Alfaro-De la Torre, M. C., Flores-Flores, J. I., Bañuelos-Hernández, B., and Patiño-Rodríguez, O. (2015). Increased accumulation of cadmium and lead under $\mathrm{Ca}$ and Fe deficiency in Typha latifolia: a case study of two pore channel (TPC1) gene. Environ. Exp. Bot. 115, 38-48. doi: 10.1016/j.envexpbot.2015.02.009

Roy, S. J., Gilliham, M., Berger, B., Essah, P. A., Cheffings, C., Miller, A. J., et al. (2008). Investigating glutamate receptor-like gene co-expression in Arabidopsis thaliana. Plant Cell Environ. 31, 861-871. doi: 10.1111/j.1365-3040.2008. 01801.x

Ruberti, C., Kim, S. J., Stefano, G., and Brandizzi, F. (2015). Unfolded protein responses in plants: one master, many questions. Curr. Opin. Plant Biol. 27, 59-66. doi: 10.1016/j.pbi.2015.05.016

Ruelland, E., Kravets, V., Derevyanchuk, M., Martinec, J., Zachowski, A., and Pokotylo, I. (2015). Role of phospholipid signalling in plant environmental responses. Environ. Exp. Bot. 114, 129143. doi: 10.1016/j.envexpbot.2014. 08.009

Sagor, G. H. M., Chawla, P., Kim, D. W., Berberich, T., Kojima, S., Niitsu, M., et al. (2015). The polyamine spermine induces the unfolded protein response via the MAPK cascade in Arabidopsis. Front. Plant Sci. 6:687. doi: 10.3389/fpls.2015.00687

Sani, E., Herzyk, P., Perrella, G., Colot, V., and Amtmann, A. (2013). Hyperosmotic priming of Arabidopsis seedlings establishes a long-term somatic memory accompanied by specific changes of the epigenome. Genome Biol. 14, R59. doi: 10.1186/gb-2013-14-6-r59

Sarwat, M., and Naqvi, A. R. (2013). Heterologous expression of rice calnexin (OsCNX) confers drought tolerance. Mol. Biol. Rep. 40, 5451-5464. doi: $10.1007 / \mathrm{s} 11033-013-2643-y$ 
Shabala, S., and Pottosin, I. (2014). Regulation of potassium transport in plants under hostile conditions: implications for abiotic and biotic stress tolerance. Physiol. Plant 151, 257-279. doi: 10.1111/ppl.12165

Shabala, S., Shabala, L., Barcelo, J., and Poschenrieder, C. (2014). Membrane transporters mediating root signalling and adaptive responses to oxygen deprivation and soil flooding. Plant Cell Environ. 37, 2216-2233. doi: $10.1111 /$ pce. 12339

Shabala, S., Wu, H., and Bose, J. (2015). Salt stress sensing and early signalling in plant roots: current knowledge and hypothesis. Plant Sci. 241, 109-119. doi: 10.1016/j.plantsci.2015.10.003

Shi, Y. T., Ding, Y. L., and Yang, S. H. (2015). Cold signal transduction and its interplay with phytohormones during cold acclimation. Plant Cell Physiol. 56, 7-15. doi: 10.1093/pcp/pcu115

Shih, H. W., Depew, C. L., Miller, N. D., and Monshausen, G. B. (2015). The cyclic nucleotide-gated channel CNGC14 regulates root gravitropism in Arabidopsis thaliana. Curr. Biol. 25, 1-7. doi: 10.1016/j.cub.2015.10.025

Shih, H.-W., Miller, N. D., Dai, C., Spalding, E. P., and Monshausen, G. B. (2014). The receptor-like kinase FERONIA is required for mechanical signal transduction in Arabidopsis seedlings. Curr. Biol. 24, 1887-1892. doi: 10.1016/j.cub.2014.06.064

Shin, R., and Schachtman, D. P. (2004). Hydrogen peroxide mediates plant root cell response to nutrient deprivation. Proc. Natl. Acad. Sci. U.S.A. 101, 8827-8832. doi: 10.1073/pnas.0401707101

Shorrocks, V. M. (1997). The occurrence and correction of boron deficiency. Plant Soil 193, 121-148. doi: 10.1023/A:1004216126069

Singh, S., Parihar, P., Singh, R., Singh, V. P., and Prasad, S. M. (2016). Heavy metal tolerance in plants: role of transcriptomics, proteomics, metabolomics, and ionomics. Front. Plant Sci. 6:1143. doi: 10.3389/fpls.2015.01143

Stael, S., Wurzinger, B., Mair, A., Mehlmer, N., Vothknecht, U. C., and Teige, M. (2012). Plant organellar calcium signalling: an emerging field. J. Expt. Bot. 63, 1525-1542. doi: 10.1093/jxb/err394

Straltsova, D., Chykun, P., Subramaniam, S., Sosan, A., Kolbanov, D., Sokolik, A., et al. (2015). cation channels are involved in brassinosteroid signalling in higher plants. Steroids 97, 98-106. doi: 10.1016/j.steroids.2014.10.008

Sulaiman, Y., Knight, M. R., and Kataky, R. (2012). Non-invasive monitoring of temperature stress in Arabidopsis thaliana roots, using ion amperometry. Anal. Meth. 4, 1656-1661. doi: 10.1039/c2ay05747f

Sunkar, R., Kaplan, B., Bouche, N., Arazi, T., Dolev, D., Talke, I. N., et al. (2000). Expression of a truncated tobacco NtCBP4 channel in transgenic plants and disruption of the homologous Arabidopsis CNGC1 gene confer $\mathrm{Pb}^{2+}$ tolerance. Plant J. 24, 533-542. doi: 10.1046/j.1365-313x.2000.00901.x

Swarbreck, S. M., Colaço, R., and Davies, J. M. (2013). Update on plant calciumpermeable channels. Plant Physiol. 163, 1514-1522. doi: 10.1104/pp.113.220855

Tai, F., Yuan, Z., Li, S. P., Wang, Q., Liu, F., and Wang, W. (2016). ZmCIPK8, a CBL-interacting protein kinase, regulates maize response to drought stress. Plant Cell Tiss. Org. Cul. 124, 459-469. doi: 10.1007/s11240-015-0906-0

Teardo, E., Carraretto, L., De Bortoli, S., Costa, A., Behera, S., and Wagner, R. (2015). Alternative splicing-mediated targeting of the Arabidopsis GLUTAMATE RECEPTOR3.5 to mitochondria affects organelle morphology. Plant Physiol. 167, 216-227. doi: 10.1104/pp.114.242602

Thion, L., Mazars, C., Nacry, P., Bouchez, D., Moreau, M., Ranjeva, R., et al. (1998). Plasma membrane depolarization-activated calcium channels, stimulated by microtubule-depolymerizing drugs in wild-type Arabidopsis thaliana protoplasts, display constitutively large activities and a longer half-life in ton 2 mutant cells affected in the organization of cortical microtubules. Plant J. 13, 603-610.

Thoday-Kennedy, E. L., Jacobs, A. J., and Roy, S. J. (2015). The role of the CBLCIPK calcium signalling network in regulating ion transport in response to abiotic stress. Plant Growth Regul. 76, 3-12. doi: 10.1007/s10725-015-0034-1

Toyota, M., and Gilroy, S. (2013). Gravitropism and mechanical signalling in plants. Am. J. Bot. 100, 111-125. doi: 10.3732/ajb.1200408

Tracy, F. E., Gilliham, M., Dodd, A. N., Webb, A. A. R., and Tester, M. (2008). $\mathrm{NaCl}$-induced changes in cytosolic free $\mathrm{Ca}^{2+}$ in Arabidopsis thaliana are heterogeneous and modified by external ionic composition. Plant Cell Environ. 31, 1063-1073. doi: 10.1111/j.1365-3040.2008.01817.x

Véry, A. A., and Davies, J. M. (2000). Hyperpolarization-activated calcium channels at the tip of Arabidopsis root hairs. Proc. Natl. Acad. Sci. U.S.A. 97, 9801-9806. doi: 10.1073/pnas.160250397
Villiers, F., Jourdain, A., Bastien, O., Leonhardt, N., Fujioka, S., Tichtincky, G., et al. (2012). Evidence for functional interaction between brassinosteroids and cadmium response in Arabidopsis thaliana. J. Expt. Bot. 63, 1185-1200. doi: $10.1093 /$ jxb/err335

Virdi, A. S., Singh, S., and Singh, P. (2015). Abiotic stress responses in plants: roles of calmodulin-regulated proteins. Front. Plant Sci. 6:809. doi: 10.3389/fpls.2015.00809

Virolainen, E., Blokhina, O., and Fagerstedt, K. (2002). $\mathrm{Ca}^{2+}$-induced high amplitude swelling and cytochrome $\mathrm{c}$ release from wheat (Triticum aestivum L.) mitochondria under anoxic stress. Ann. Bot. 90, 509-516. doi: $10.1093 / \mathrm{aob} / \mathrm{mcf} 221$

Wagner, S., Behera, S., De Bortoli, S., Logan, D. C., Fuchs, P., and Carraretto, L. (2015). The EF-Hand $\mathrm{Ca}^{2+}$-binding protein MICU choreographs mitochondrial $\mathrm{Ca}^{2+}$ dynamics in Arabidopsis. Plant Cell 27, 3190-3212. doi: 10.1105/tpc.15.00509

Wan, S., and Jiang, L. (2016). Endoplasmic reticulum (ER) stress and the unfolded protein response (UPR) in plants. Protoplasma 273, 753-764. doi: 10.1007/s00709-015-0842-1

Wang, F. F., Chen, Z. H., Liu, X. H., Colmer, T. D., Zhou, M. X., and Shabala, S. (2016). Tissue-specific root ion profiling reveals essential roles of the CAX and ACA calcium transport systems in response to hypoxia in Arabidopsis. J. Expt. Bot. 67, 3747-3762. doi: 10.1093/jxb/erw034

Wang, P., Li, Z. W., Wei, J. S., Zhao, Z. L., Sun, D. Y., and Cui, S. J. (2012). $\mathrm{A} \mathrm{Na}^{+} / \mathrm{Ca}^{2+}$ exchanger-like protein (AtNCL) involved in salt stress in Arabidopsis. J. Biol. Chem. 287, 44062-44070. doi: 10.1074/jbc.M112.351643

Weiland, M., Mancuso, S., and Baluska, F. (2016). Signalling via glutamate and GLRs in Arabidopsis thaliana. Funct. Plant Biol. 43, 1-25.

Whalley, H. J., and Knight, M. R. (2013). Calcium signatures are decoded by plants to give specific gene responses. New Phytol. 197, 690-693. doi: 10.1111/nph.12087

Whalley, H. J., Sargeant, A. W., Steele, J. F., Lacoere, T., Lamb, R., Saunders, N. J., et al. (2011). Transcriptomic analysis reveals calcium regulation of specific promoter motifs in Arabidopsis. Plant Cell 23, 4079-4095. doi: 10.1105/tpc.111.090480

White, P. J. (2009). Depolarization-activated calcium channels shape the calcium signatures induced by low-temperature stress. New Phytol. 183, 7-8. doi: 10.1111/j.1469-8137.2009.02857.x

Wigge, P. A. (2013). Ambient temperature signalling in plants. Curr. Opn. Plant Biol. 16, 661-666. doi: 10.1016/j.pbi.2013.08.004

Wu, J. Y., Jin, C., Qu, H. Y., Tao, S. T., Xu, G. H., Wu, J., et al. (2012). Low temperature inhibits pollen viability by alteration of actin cytoskeleton and regulation of pollen plasma membrane ion channels in Pyrus pyrifolia. Environ. Expt. Bot. 78, 70-75. doi: 10.1016/j.envexpbot.2011.12.021

Xu, Q. T., Fan, H. Y., Jiang, Z., Zhou, Z. Q., Yang, L., Mei, F. Z., et al. (2013). Cell wall degradation and the dynamic changes of $\mathrm{Ca}^{2+}$ and related enzymes in the developing aerenchyma of wheat (Triticum aestivum L.) under waterlogging. Acta Biol. Hung. 64, 328-340. doi: 10.1556/ABiol.64.2013.3.6

Yamada, N., Theerawitaya, C., Ca-Um, S., Kirdmanee, C., and Takabe, T. (2014). Expression and functional analysis of putative vacuolar $\mathrm{Ca}^{2+}$-transporters (CAXs and ACAs) in roots of salt tolerant and sensitive rice cultivars. Protoplasma 251, 1067-1075. doi: 10.1007/s00709-014-0615-2

Yamauchi, T., Watanabe, K., Fukazawa, A., Mori, H., Abe, F., Kawaguchi, K., et al. (2014). Ethylene and reactive oxygen species are involved in root aerenchyma formation and adaptation of wheat seedlings to oxygen-deficient conditions. J. Expt. Bot. 65, 261-273. doi: 10.1093/jxb/ert371

Yang, C.-Y., and Hong, C.-P. (2015). The NADPH oxidase RbohD is involved in primary hypoxia signalling and modulates expression of hypoxiainducible genes under hypoxic stress. Env. Expt. Bot. 115, 63-72. doi: 10.1016/j.envexpbot.2015.02.008

Yang, T. B., Chaudhuri, S., Yang, L. H., Du, L. Q., and Poovaiah, B. W. (2010). A calcium/calmodulin-regulated member of the receptor-like kinase family confers cold tolerance in plants. J. Biol. Chem. 285, 7119-7126. doi: 10.1074/jbc.M109.035659

Yeh, C. M., Chien, P. S., and Huang, H. J. (2007). Distinct signalling pathways for induction of MAP kinase activities by cadmium and copper in rice roots. J. Expt. Bot. 58, 659-671. doi: 10.1093/jxb/erl240

Yemelyanov, V. V., Shishova, M. F., Chirkova, T. V., and Lindberg, S. M. (2011). Anoxia-induced elevation of cytosolic $\mathrm{Ca}^{2+}$ concentration depends on 
different $\mathrm{Ca}^{2+}$ sources in rice and wheat protoplasts. Planta 234, 271-280. doi: 10.1007/s00425-011-1396-x

Yu, H. Q., Yong, T. M., Li, H. J., Liu, Y. P., Zhou, S. F., Fu, F. L., et al. (2015). Overexpression of a phospholipase D alpha gene from Ammopiptanthus nanus enhances salt tolerance of phospholipase D alpha 1-deficient Arabidopsis mutant. Planta 242, 1495-1509. doi: 10.1007/s00425-015-2390-5

Yu, L. J., Nie, J. N., Cao, C. Y., Jin, Y. K., Yan, M., Wang, F. Z., et al. (2010). Phosphatidic acid mediates salt stress response by regulation of MPK6 in Arabidopsis thaliana. New Phytol. 188, 762-773. doi: 10.1111/j.14698137.2010.03422.x

Yu, Y. Q., and Assmann, S. M. (2015). The heterotrimeric G-protein beta subunit, AGB1, plays multiple roles in the Arabidopsis salinity response. Plant Cell Environ. 38, 2143-2156. doi: 10.1111/pce.12542

Yuan, F., Yang, H., Xue, Y., Kong, D., Ye, R., Li, C., et al. (2014). OSCA1 mediates osmotic-stress-evoked $\mathrm{Ca}^{2+}$ increases vital for osmosensing in Arabidopsis. Nature 514, 367-371. doi: 10.1038/nature13593

Yuan, H.-M., and Huang, X. (2016). Inhibition of root meristem growth by cadmium involves nitric oxide-mediated repression of auxin accumulation and signalling in Arabidopsis. Plant Cell Environ. 39, 120-135. doi: 10.1111/pce. 12597

Yuen, C. C. Y., and Christopher, D. A. (2013). The group IV-A cyclic nucleotidegated channels, CNGC19 and CNGC 20, localize to the vacuole membrane in Arabidopsis thaliana. AoB Plants 5, plt012. doi: 10.1186/1471-2164-15-853

Zelinova, V., Alemayehu, A., Bocova, B., Huttova, J., and Tamas, L. (2015). Cadmium-induced reactive oxygen species generation, changes in morphogenic responses and activity of some enzymes in barley root tip are regulated by auxin. Biologia 70, 356-364. doi: 10.1515/biolog-2015-0035

Zeng, F., Konnerup, D., Shabala, L., Zhou, M., Colmer, T. D., Zhang, G., et al. (2014). Linking oxygen availability with membrane potential maintenance and $\mathrm{K}^{+}$retention of barley roots: implications for waterlogging stress tolerance. Plant Cell Environ. 37, 2325-2338. doi: 10.1111/pce.12422

Zeng, Q., Ling, Q., Fan, L., Li, Y., Hu, F., Chen, J., et al. (2015). Transcriptome profiling of sugarcane roots in response to potassium stress. PLoS ONE 10:e0126306. doi: 10.1371/journal.pone.0126306

Zepeda-Jazo, I., Maria Velarde-Buendia, A., Enriquez-Figueroa, R., Bose, J., Shabala, S., Muniz-Murguia, J., et al. (2011). Polyamines interact with hydroxyl radicals in activating $\mathrm{Ca}^{2+}$ and $\mathrm{K}^{+}$transport across the root epidermal plasma membranes. Plant Physiol. 157, 2167-2180. doi: 10.1016/j.plaphy.2012. 09.002
Zhang, L., Chen, Z., and Zhu, C. (2012). Endogenous nitric oxide mediates alleviation of cadmium toxicity induced by calcium in rice seedlings. J. Environ. Sci. 24, 940-948. doi: 10.1016/S1001-0742(11)60978-9

Zhang, X., Shen, Z. D., Sun, J., Yu, Y. C., Deng, S. R., and Li, Z. Y. (2015). NaClelicited, vacuolar $\mathrm{Ca}^{2+}$ release facilitates prolonged cytosolic $\mathrm{Ca}^{2+}$ signaling in the salt response of Populus euphratica cells. Cell Calcium 57, 348-365. doi: 10.1016/j.ceca.2015.03.001

Zhang, Y., Wang, Y., Taylor, J. L., Jiang, Z., Zhang, S., Mei, F., et al. (2015). Aequorin-based luminescence imaging reveals differential calcium signalling responses to salt and reactive oxygen species in rice roots. J. Expt. Bot. 66, 2535-2545. doi: 10.1093/jxb/erv043

Zhao, M. G., Tian, Q. Y., and Zhang, W. H. (2007). Ethylene activates a plasma membrane $\mathrm{Ca}^{2+}$-permeable channel in tobacco suspension cells. New Phytol. 174, 507-515. doi: 10.1111/j.1469-8137.2007.02037.x

Zhao, R., Sun, H. M., Zhao, N., Jing, X. S., Shen, X., and Chen, S. (2015). The Arabidopsis $\mathrm{Ca}^{2+}$-dependent protein kinase CPK27 is required for plant response to salt-stress. Gene 563, 203-214. doi: 10.1016/j.gene.2015.03.024

Zhao, Y., Pan, Z., Zhang, Y., Qu, X. L., Zhang, Y. G., and Yang, Y. G. (2013). The Actin-Related Protein $2 / 3$ complex regulates mitochondrial-associated calcium signaling during salt stress in Arabidopsis. Plant Cell 25, 4544-4559. doi: 10.1105/tpc.113.117887

Zhu, S.-Y., Yu, X.-C., Wang, X.-J., Zhao, R., Li, Y., Fan, R.-C., et al. (2007). Two calcium-dependent protein kinases, CPK4 and CPK11, regulate abscisic acid signal transduction in Arabidopsis. Plant Cell 19, 3019-3036. doi: 10.1105/tpc.107.050666

Zhu, X. H., Feng, Y., Liang, G. M., Liu, N., and Zhu, J. K. (2013). Aequorin-based luminescence imaging reveals stimulus- and tissue-specific $\mathrm{Ca}^{2+}$ dynamics in Arabidopsis plants. Mol. Plant 6, 444-455. doi: 10.1093/mp/sst013

Conflict of Interest Statement: The authors declare that the research was conducted in the absence of any commercial or financial relationships that could be construed as a potential conflict of interest.

Copyright (c) 2016 Wilkins, Matthus, Swarbreck and Davies. This is an open-access article distributed under the terms of the Creative Commons Attribution License (CC BY). The use, distribution or reproduction in other forums is permitted, provided the original author(s) or licensor are credited and that the original publication in this journal is cited, in accordance with accepted academic practice. No use, distribution or reproduction is permitted which does not comply with these terms. 